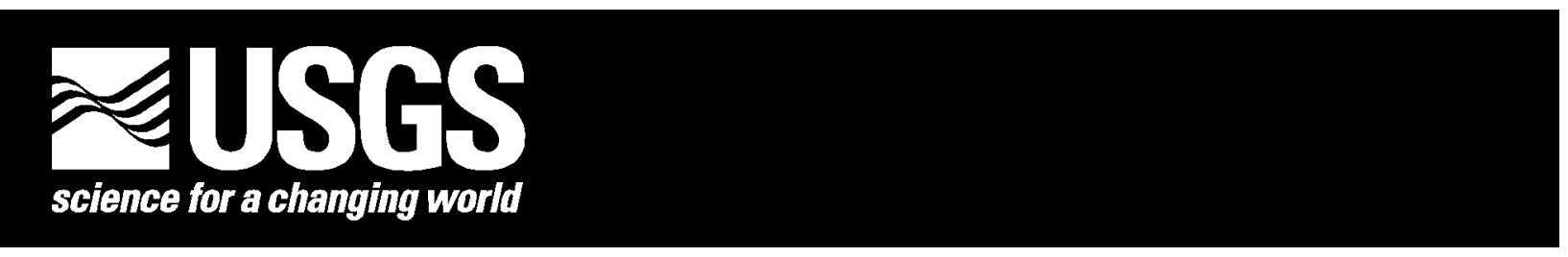

U.S. DEPARTMENT OF THE INTERIOR

U.S. GEOLOGICAL SURVEY

\title{
GEOLOGIC MAP OF THE GRAND JUNCTION QUADRANGLE, MESA COUNTY, COLORADO
}

By

Robert B. Scott ${ }^{1}$, Paul E. Carrara ${ }^{1}$, William C. Hood ${ }^{2}$, and Kyle E. Murray ${ }^{1}$

${ }^{1}$ U.S. Geological Survey, Denver, CO 80225

2515 Dove Court, Grand Junction, CO 81503

2002

Pamphlet to accompany

MISCELLANEOUS FIELD STUDIES MAP

MF-2363 


\title{
DESCRIPTION OF MAP UNITS
}

\author{
INTRODUCTION
}

The surficial map units on this map are informal allostratigraphic units of the North American Stratigraphic Code (North American Commission on Stratigraphic Nomenclature, 1983), whereas the bedrock units are lithostratigraphic units. Therefore, subdivisions of time for stratigraphic units use the terms "late" and "early" for surficial units, but use the terms "upper" and "lower" for bedrock units.

Surficial deposits shown on the map are estimated to be at least $1 \mathrm{~m}$ thick. Thin, discontinuous colluvial deposits, residual material on bedrock, and some artificial fills were not mapped. Fractional map symbols (for example, Qse/Qt30) are used where a thin veneer of a younger unit mantles identified older surficial deposits. Many contacts of surficial deposits are approximate, and therefore, are shown as dashed contacts [for example; the contact between undivided alluvium and colluvium $(\mathrm{Qac})$ and terrace alluvium $30(\mathrm{Qt} 30)$ south of the Colorado River]. North of the Colorado River, the contacts between undivided alluvium and colluvium (Qac) and alluvial deposits Qalc1 and Qalc2 are poorly exposed or gradational.

Age assignments for surficial deposits are based chiefly on stratigraphic relationships and the degree of erosional modification of original surface morphology. In addition, age assignments for alluvial deposits (Qt30, Qt60, Qt100, and Qt170) are based on the height of the deposit above the Colorado River. Age assignments for terrace alluvium units are based chiefly on two regional rates of stream incision of about $0.14 \mathrm{~m} / \mathrm{ky}(\mathrm{ky}$, thousands of years) and $0.16 \mathrm{~m} / \mathrm{ky}$, and on a local rate of incision of about $0.15 \mathrm{~m} / \mathrm{ky}$. The first incision rate $(0.14 \mathrm{~m} / \mathrm{ky})$ is based on an average of three values for incision since deposition of the 640 $\pm 4-\mathrm{ka}$ (M.A. Lanphere, U.S. Geological Survey, written commun., 2000) (ka, thousand years ago) Lava Creek B volcanic ash: (1) about $85 \mathrm{~m}$ along the Colorado River near the east end of Glenwood Canyon (Izett and Wilcox, 1982), (2) about $88 \mathrm{~m}$ along the Roaring Fork River near Carbondale, Colorado (Piety, 1981), and (3) about 80-85 $\mathrm{m}$ along the White River near Meeker, Colorado (J.W. Whitney, U.S. Geological Survey, oral commun., 1992; Whitney and others, 1983). The second incision rate $(0.16 \mathrm{~m} / \mathrm{ky})$, possibly a minimum rate, is based on about $1,525 \mathrm{~m}$ of downcutting by the Colorado River after eruption of $9.7 \pm 0.05-\mathrm{Ma}$ (Ma, million years ago) basaltic rocks on Grand Mesa (Marvin and others, 1966) about $30 \mathrm{~km}$ east of the map area. A local rate of stream incision of 0.15 $\mathrm{m} / \mathrm{ky}$ is based on the presence of the Lava Creek B volcanic ash about $91 \mathrm{~m}$ above the drainage at a site on the Harley Dome 7.5' quadrangle in Utah (lat 39¹3.52', long $\left.109^{\circ} 10.44^{\prime}\right)$ (Willis, 1994). This identification was reconfirmed by major-element analyses by Andrei-Wocjicki (U.S. Geological Survey, written commun., 2000) and by trace-element analyses by Jim Budahn (U.S. Geological Survey, written commun., 2000). Another ash collected by Rex Cole (Mesa State College) and Paul Carrara $1.8 \mathrm{~km}$ east of the Utah border (lat 39²0.166', long $\left.109^{\circ} 01.770^{\prime}\right)$ on the Bar X 7.5' quadrangle could not be positively identified as Lava Creek B ash because of alteration. This ash is also about $91 \mathrm{~m}$ above the local drainage.

Most of the surficial deposits are calcareous and contain variable amounts of primary and secondary calcium carbonate; stages of secondary calcium carbonate morphology (referred to as stages I through III in this report) are those of Gile and others (1966). Grain sizes (table 1) given for surficial deposits and bedrock are based on field estimates and follow the modified Wentworth scale (American Geological Institute, 1982). In descriptions of surficial map units, the term "clasts" refers to the fraction greater than $2 \mathrm{~mm}$ in diameter, whereas the term "matrix" refers to the particles less than $2 \mathrm{~mm}$ in size. Dry matrix colors of the surficial deposits were determined by comparison with Munsell Soil Color Charts (Munsell Color, 1973). Bedrock colors were determined by comparison with the Geological Society of America Rock-Color Chart (Rock-Color Chart Committee, 1951).

Table 1. Grain sizes in metric and English units (American Geological Institute, 1982)

\begin{tabular}{lll}
\hline Clay & less than $0.0004 \mathrm{~mm}$ & less than $0.00016 \mathrm{in}$. \\
Silt & $0.0004-0.062 \mathrm{~mm}$ & $0.00016-0.0025 \mathrm{in}$. \\
Sand & $0.062-2 \mathrm{~mm}$ & $0.0025-0.08 \mathrm{in}$. \\
& & \\
Granule & $2-4 \mathrm{~mm}$ & $0.08-0.16 \mathrm{in}$. \\
Pebble & $4-64 \mathrm{~mm}$ & $0.16-2.5 \mathrm{in}$. \\
Cobble & $64-256 \mathrm{~mm}$ & $2.5-10 \mathrm{in}$. \\
Boulder & greater than $256 \mathrm{~mm}$ & greater than $10 \mathrm{in}$. \\
\hline
\end{tabular}

With the exception of the Mancos Shale, bedrock is limited to the southwestern and southern parts of the map area, close to exposures of the same units in the adjacent Colorado National Monument 7.5' quadrangle; therefore, descriptions are largely taken from those of Scott and others (2001). Sedimentary bedrock terms follow the classifications of Folk (1974) for sandstones and conglomerates, Dunham (1962) for carbonate rocks, and Picard (1971) for mudstones (we use "mudstone" in place of Picard's term "mudrock"). Bedding thickness terms follow those of Ingram (1954) and Potter and others (1980). Degree of sorting terms follow those of Pettijohn and others (1973) and Folk (1974). Grain shape terms follow those of Powers (1953); sedimentary 
structure terms follow those of McKee and Weir (1953), Campbell (1967), Allen (1970), and Boggs (1995); and fossil and trace fossil terms follow those of Ekdale and others (1984) and Pemberton and others (1992).

Metric units are used in this report; a conversion table is provided for those more familiar with English units (table 2). A review of the divisions of geologic time used in this report is also provided (table 3 ).

Table 2. Factors for conversion of metric units to English units to two significant figures

\begin{tabular}{lll}
\hline Multiply & By & To obtain \\
\hline centimeters $(\mathrm{cm})$ & 0.39 & inches (in) \\
meters $(\mathrm{m})$ & 3.3 & feet $(\mathrm{ft})$ \\
kilometers $(\mathrm{km})$ & 0.62 & miles $(\mathrm{mi})$ \\
kilograms & 2.2 & pounds $(\mathrm{lb})$ \\
kilograms per cubic meter $\left(\mathrm{kg} / \mathrm{m}^{3}\right)$ & 0.062 & pounds per cubic foot $\left(\mathrm{lb} / \mathrm{ft}{ }^{3}\right)$ \\
\hline
\end{tabular}

Table 3. Definitions of divisions of geologic time used in this report

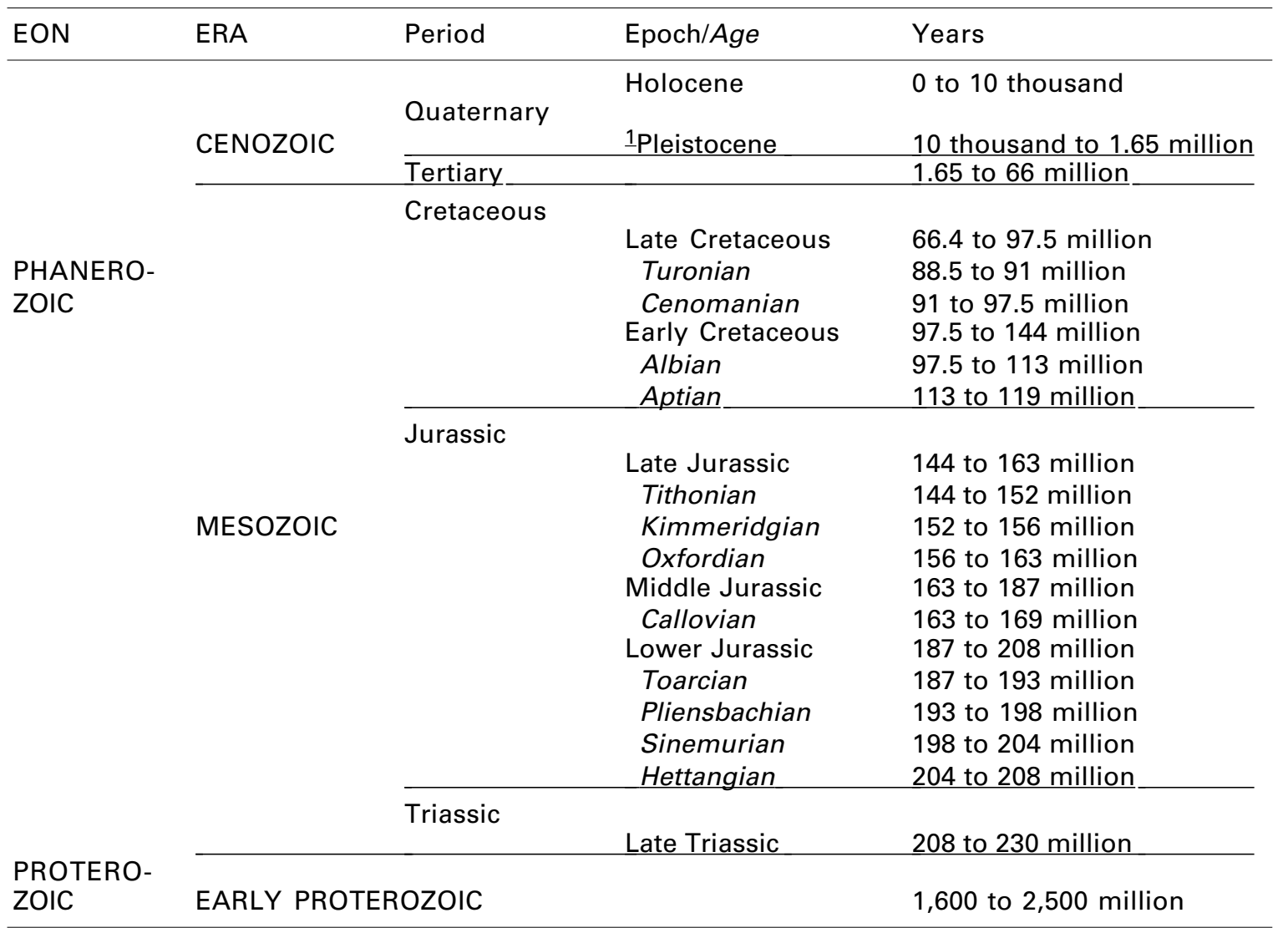

After Hansen (1991) except for the Pleistocene.

${ }^{1}$ Subdivisions of Pleistocene time are informal and are as follows: late Pleistocene is 10-132 thousand years, middle Pleistocene is 132-788 thousand years, and early Pleistocene is 788-1,650 thousand years (Richmond and Fullerton, 1986). Subdivisions of the Cretaceous, Jurassic, and Triassic follow those of Geological Society of America (1999). 


\section{SURFICIAL UNITS}

Artificial-fill deposits-Compacted and uncompacted material composed mostly of silt, sand, and rock fragments placed beneath and adjacent to highways, railroads, airstrips, stock ponds, and earthen dams

af

Artificial fill (latest Holocene)-Compacted and uncompacted fill material composed mostly of varying amounts of silt, sand, and rock fragments. Unit includes fills beneath Interstate 70 (I-70) and the Denver and Rio Grande Western Railroad. Besides the normal aggregate sub-base, fill beneath I-70 consists of local additions of predominantly locally (but outside the map area) derived materials consisting mostly of massive, silty sand containing scattered pebble- and cobble-size angular clasts derived from Mesaverde Group sandstone. Fill beneath the Denver and Rio Grande Western Railroad consists of unstratified, well-sorted, pebble- and cobble-size, angular to subangular basaltic rocks. The fill beneath the airstrips at Walker Field was not observed but must be substantial, particularly where runways overlie the Mancos Shale $(\mathrm{Km})$. Poorly compacted fills may be subject to settlement when loaded. Thickness ranges from about 1 to $5 \mathrm{~m}$

Alluvial deposits - Silt, sand, and gravel in stream channels, floodplains, and terraces along the Colorado and Gunnison Rivers and tributaries

Qalc1 Youngest alluvium deposited by the Colorado River (Holocene)-Alluvium underlying the Colorado River channel and floodplain. The upper $1-2 \mathrm{~m}$ of the unit is commonly an overbank deposit and consists of light-yellowish-brown (10YR 6/4), massive, silty fine sand to medium sand that locally contains minor amounts of pebbles and cobbles in lenses generally less than $20 \mathrm{~cm}$ thick. The lower part of the unit, which is poorly exposed, consists of well-sorted, rounded and well-rounded, slightly bouldery pebble-cobble gravel derived from a variety of igneous, metamorphic, and sedimentary rocks in a sandy matrix. Along the Colorado River, upstream from the confluence with the Gunnison River, clasts consist mainly of basaltic rocks, quartzite, pale-red micaceous sandstone derived from the Maroon Formation, light- to medium-gray, fine-grained and mediumgrained porphyritic granitic rocks, and distinctive, very pale orange weathering, "oil shale" clasts of the Green River Formation. Downstream from the confluence of the Colorado and Gunnison Rivers, clasts consist of similar rock types with the addition of intermediate-composition volcanic and hypabyssal rocks derived from the San Juan Mountains to the southeast and the West Elk Mountains to the east. Exposures in gravel pits (boundary of pits delineated by short dashed lines) locally display scour-and-fill structures. Some clasts have thin $(1-2 \mathrm{~mm})$, white carbonate coats. Matrix in gravel part of unit consists of very pale brown (10YR 7/4) sandy silt and silty sand. The map unit includes low terraces along the floodplain. Along the Colorado River, the northern boundary of the map unit was covered by a wedge of undivided alluvium and colluvium (Qac) derived from the Book Cliffs, which are north of the Grand Junction quadrangle. The boundary of unit Qalc1 north of the Colorado River is only approximately located where the alluvial and colluvial wedge is thought to be less than $2 \mathrm{~m}$ thick, based on analysis of well-log data (Schneider, 1975; Phillips, 1986). The map unit is subject to periodic flooding, particularly during spring runoff from snow melt. The map unit is an important gravel resource; based on the thickness of similar gravels on terraces bordering the floodplain and on well-log data (Schneider, 1975; Phillips, 1986), the gravel in this unit is generally $5-12 \mathrm{~m}$ thick

Qalg Youngest alluvium deposited by the Gunnison River (Holocene)-Alluvium underlying the Gunnison River channel and floodplain. The upper $1-2 \mathrm{~m}$ of the unit, commonly an overbank deposit, consists of light-yellowish-brown (10YR 6/4), massive, silty fine sand to medium sand. The lower part of the unit, which is poorly exposed, consists of wellsorted, rounded and well-rounded pebble-cobble gravel derived from a variety of igneous, metamorphic, and sedimentary rocks. Clasts consist mainly of intermediatecomposition volcanic rocks, basaltic rocks, quartzite, red sandstone, and gray fine-grained and medium-grained granitic rocks in a sandy matrix. Alluvium deposited by the Gunnison River (Qalg) differs from younger alluvium deposited by the Colorado River (Qalc1) by containing intermediate-composition volcanic clasts, by not containing clasts of the Green River Formation and the micaceous sandstone of the Maroon Formation, and by not containing boulder-size clasts. Some clasts have thin (1-2 mm), white carbonate coats. Matrix in gravel part of unit consists of very pale brown (10YR 7/4) sandy silt and silty sand. The map unit includes low terraces along the floodplain and is subject to periodic flooding particularly during spring runoff from snow melt. The map unit is a gravel resource; based on the thickness of similar gravels on terraces bordering the river, the gravel in this unit is generally $5-10 \mathrm{~m}$ thick

Qa Alluvium deposited by tributary streams (Holocene and late Pleistocene)-Alluvium underlying stream channels, floodplains, and low terraces deposited by small tributary 
streams. North of the Colorado River, the unit consists of poorly stratified to wellstratified, poorly sorted to well-sorted, cobbly pebble gravel layers in a light-yellowishbrown (10YR 6/4) fine sand and silty sand matrix. Clasts are commonly subrounded to rounded, and consist of shale and sandstone fragments derived from the Mancos Shale $(\mathrm{Km})$ and the Mesaverde Group. In places it also consists of light-brownish-gray (2.5Y $6 / 2$ ), massive sand and sandy silt that contains scattered pebble layers or lenses generally less than $10 \mathrm{~cm}$ thick. South of the Colorado River, the map unit includes minor undifferentiated colluvial deposits such as young fan-alluvium and debris-flow deposits (Ofy) and sheetwash deposits. Locally, the map unit includes boulders as large as $2 \mathrm{~m}$ in diameter. The map unit typically consists of interbedded sand, pebbly sand, and pebble gravel, and ranges from thin-bedded $(0.5-0.10 \mathrm{~cm}$ ) clayey, silty sand to thick-bedded (> $1 \mathrm{~m}$ ), poorly sorted, both clast- and matrix-supported, slightly bouldery, pebble and cobble gravel with a sand matrix. Little or no secondary carbonate is present. Low-lying areas of the map unit are prone to periodic flooding and debris-flow deposition from summer thunderstorms. Maximum thickness of the map unit is about $5 \mathrm{~m}$

Valley-fill deposit (Holocene and late Pleistocene)-Chiefly stream-terrace alluvium and probably sandy debris-flow deposits, but also locally includes stony colluvium on valley sides as well as minor deposits of eolian sand and sheetwash. The only exposure of the map unit exists in the southwestern part of the map area within the Colorado National Monument. In the adjacent Colorado National Monument 7.5' quadrangle, valley-fill deposits can be subdivided into a thicker bedded $(>30 \mathrm{~cm})$, slightly calcareous upper part and a thinner bedded $(<30 \mathrm{~cm})$, calcareous lower part (Scott and others, 2001). Both parts are largely composed of sand and silt that contain small, discontinuous lenses of gravel. Both parts locally contain several buried, weakly developed paleosols and common small $(<2 \mathrm{~mm})$ charcoal fragments. Some of these paleosols are darker than the rest of the map unit Qvf from the accumulation of organic matter, and contain abundant charcoal, presumably from burnt woody vegetation. Charcoal not associated with paleosols is concentrated at bedding breaks in the sediments, but charcoal also occurs within beds. Charcoal ${ }^{14} \mathrm{C}$ laboratory values range from $1,280 \pm 50$ to $9,190 \pm 50$ years BP (before present, referenced at 1950) (Scott and others, 1999), and calibrated ages (Stuiver and others, 1998) range from 1,180 to 10,360 years BP. The discovery in No Thoroughfare Canyon of a mastodon tooth, which was probably eroded from the undated lowest part of the map unit, is consistent with a late Pleistocene age for the oldest part of the unit. The upper part of unit Qvf has beds that are typically $0.1-2 \mathrm{~m}$ thick, is generally reddish brown (5YR 5/4) to yellowish red (5YR 5/8), and contains minor charcoal fragments. The lower part typically has beds $5-50 \mathrm{~cm}$ thick, is yellow (2.5Y 7/6) to reddish yellow (7.5YR 6/6), and locally light olive brown (2.5Y 5/4), has iron oxide staining, and contains more charcoal fragments and fewer gravel lenses than the upper part. The lower part is weakly indurated, due in part to secondary calcium carbonate in a stage II Bk horizon. The gravel lenses in the lower part can be traced only a few meters at most, are about $2-5 \mathrm{~cm}$ thick, and consist chiefly of small granules and pebbles. Unit Qvf may be as much as $18 \mathrm{~m}$ thick in the map area Alluvium that underlies an area along the north side of the Colorado River west of Grand Junction. This area is about 3-5 $\mathrm{m}$ above the river and is not considered to be part of the active floodplain of the younger alluvium deposited by the Colorado River (Qalc1). The map unit is poorly exposed; locally, rounded and well-rounded pebble-cobble gravel of Colorado River origin is exposed at surface or in shallow excavations. Clasts include mainly basaltic rocks, light- to medium-gray fine-grained granitic rocks, fine-grained red micaceous sandstone, quartzite, and very light gray and pinkish-gray coarse-grained granitic rocks. Some clasts have a thin $(1-2 \mathrm{~mm})$, white carbonate coat. Gravel is commonly overlain by 1-2 m of overbank deposit and possibly eolian materials consisting of massive, light-yellowish-brown (10YR 6/4) silty fine sand and fine sand. Lower parts of the map unit may be subject to flooding by infrequent large flood events. The map unit is a gravel resource, and well-log data (Schneider, 1975; Phillips, 1986) indicate that it is about $5 \mathrm{~m}$ thick

Qtgu Terrace alluvium of the Gunnison River, undivided (late to middle Pleistocene)-Alluvium deposited by the Gunninson River that underlies small terrace remnants between about 10 and $90 \mathrm{~m}$ above the river in the southeast part of the map area. The map unit consists mainly of well-sorted, rounded to well-rounded pebble-cobble gravel with some boulders. Clasts consist mainly of intermediate-composition volcanic rocks, basaltic rocks, quartzite, and gray fine-grained and medium-grained granitic rocks in a sandy matrix. The matrix of the gravel component of the map unit consists of very pale brown (10YR $7 / 4$ ) sandy silt and silty sand. Gravels are commonly overlain by 1-2 m of massive, light 
yellowish-brown (10YR 6/4) clayey silt, silty fine sand, and fine sand containing scattered pebbles and cobbles. The map unit is commonly $5-10 \mathrm{~m}$ thick

Terrace alluvium 30 of the Colorado River (middle Pleistocene)-Alluvium deposited by the Colorado River along its south side underlies a prominent terrace about 24-37 $\mathrm{m}$ above the river. The map unit consists mainly of well-sorted, rounded to well-rounded pebblecobble gravel with some boulders. Above the confluence with the Gunnison River, clasts consist predominantly of basaltic rocks (29\%), quartzite (25\%), fine-grained granitic rocks $(15 \%)$, and fine-grained micaceous red sandstone (11\%). Below the confluence with the Gunnison River, gravel also contains andesitic and dacitic clasts. All clasts of the "oil shale" of the Green River Formation in exposures are highly shattered and (or) thoroughly weathered. The matrix consists of pale-brown (10YR 6/3) silty sand and sand, forming about 5-10\% of the map unit. Gravels are commonly overlain by 1-2 $\mathrm{m}$ of massive, light-yellowish-brown (10YR 6/4) clayey silt, silty fine sand, and fine sand containing scattered pebbles and cobbles. Unit Qt30 contains lenses of light-gray (10 YR $7 / 2$ ), well-sorted, cross-bedded, coarse to medium sand that are $25-50 \mathrm{~cm}$ thick containing thin $(<5 \mathrm{~cm})$ pebble layers. In places, the upper $30 \mathrm{~cm}$ of gravel contains abundant platy shale clasts derived from the Green River Formation. The map unit underlies Orchard Mesa and much of The Redlands, south of the Colorado River. In The Redlands area, probably some unmapped old alluvial-slope deposits (Qaso) locally overlie unit Qt30; extensive landscaping has made more detailed subdivisions impractical. On Orchard Mesa, an alluvial and colluvial (Qac) wedge composed of fine-grained sediment was deposited northward from hills to the south to cover the southern boundary of this unit (Schwochow, 1978). The southern boundary is only approximately located where the alluvial and colluvial wedge is thought to be less than $2 \mathrm{~m}$ thick (Schwochow, 1978). Based on the height of this map unit above the Colorado River, it is equivalent to unit Qt2 in the adjacent Clifton quadrangle (Carrara, 2001) and is probably equivalent in part to outwash of the Bull Lake glaciation, which is about 140-150 ka (Pierce and others, 1976). If so, the rate of incision during the past $150 \mathrm{ky}$ was about $0.16-0.26 \mathrm{~m} / \mathrm{ky}$, probably higher than the rate of $0.15 \mathrm{~m} / \mathrm{ky}$ that was determined for the past $620 \mathrm{ky}$. The map unit was actively mined for gravel during 1999 on the Clifton quadrangle to the east, near the junction of $\mathrm{C} 1 / 2$ and 32 Roads, and at the northern end of 31 Road south of the Colorado River (Carrara, 2001). The thickness of unit Qt30 is commonly 5-10 m Colorado River that underlies terrace remnants about 64-67 $\mathrm{m}$ above the river south of The Redlands area in the west-central part of the map area. The map unit consists of abundant well-sorted, rounded to well-rounded pebble-cobble gravel and less common boulders. Clasts consist predominantly of basaltic rocks, quartzite, fine-grained granitic rocks, fine-grained micaceous red sandstone, and intermediate-composition volcanic rocks such as andesitic and dacitic rocks. All "oil shale" clasts of the Green River Formation are highly shattered and (or) thoroughly weathered. The matrix consists of pale-brown (10YR 6/3) silty sand and sand, forming about $5-10 \%$ of the unit. Gravels are commonly overlain by 1-2 m of massive, light-yellowish-brown (10YR 6/4) clayey silt, silty fine sand, and fine sand containing scattered pebbles and cobbles. The map unit contains lenses of light-gray (10 YR 7/2), well-sorted, cross-bedded, coarse to medium sand $25-50 \mathrm{~cm}$ thick containing thin $(<5 \mathrm{~cm})$ pebble layers. Based on the height of this unit above the Colorado River and a regional rate of stream incision of about $0.15 \mathrm{~m} / \mathrm{ky}$, the terrace remnants of this unit may be about 425-445 ka. Unit Qt60c is commonly 5$10 \mathrm{~m}$ thick Gunnison River that underlies terrace remnants about 55-64 m above the river south of The Redlands area in the west-central part of the map area near Little Park Road and in the southeast part of the map area. The map unit consists mainly of well-sorted, rounded to well-rounded pebble-cobble gravel with some boulders. Clasts consist predominantly of basaltic rocks, quartzite, fine-grained granitic rocks, fine-grained red sandstone, and intermediate-composition volcanic rocks such as andesitic and dacitic rocks. The matrix consists of pale-brown (10YR 6/3) silty sand and sand, forming about $5-10 \%$ of the map unit. Gravels are commonly overlain by $1-2 \mathrm{~m}$ of massive, lightyellowish-brown (10YR 6/4) clayey silt, silty fine sand, and fine sand containing scattered pebbles and cobbles. The map unit contains lenses of light-gray (10YR 7/2), well-sorted, cross-bedded, coarse to medium sand that is $25-50 \mathrm{~cm}$ thick and contains thin $(<5 \mathrm{~cm})$ pebble layers. There is no terrace alluvium upstream in the Clifton quadrangle that occurs at heights equivalent to those of this map unit; in the Colorado National Monument quadrangle downstream from this map area, terrace alluvium heights include those at about 65 and $75 \mathrm{~m}$ above the river. Based on the height of this unit above the 
Qtc/Qtg

Qt100

Qt170

$$
\text { of about } 10 \mathrm{~m}
$$

Alluvial and colluvial deposits-Mostly silt, sand, and gravel in alluvial and colluvial slope deposits and old dissected debris-flow deposits on pediment surfaces

Qfy

Colorado River and a regional rate of stream incision of about $0.15 \mathrm{~m} / \mathrm{ky}$, the terrace remnants of this unit may be about 365-425 ka. The thickness of unit Qt60g commonly is $5-10 \mathrm{~m}$

Terrace alluvium of the Colorado River over terrace alluvium of the Gunnison River (middle Pleistocene)-Remnant terrace alluvium of the Colorado River overlies the terrace alluvium of the Gunnison River in at least two localities north of the Gunnison River. The lowest (65-75 m above the river) is $1 \mathrm{~km}$ southeast of the AEC (DOE) Grand Junction Compound just upstream from the junction of the Gunnison with the Colorado, and the highest (90-105 m above the river) is $1.5 \mathrm{~km}$ northeast of Horse Point in the southeastern part of the map area. Clasts described for terrace alluvium 60 of the Gunnison River $(\mathrm{Qt} 60 \mathrm{~g})$ and for terrace alluvium 100 of the Colorado River (Qt100) are similar to those found in this map unit. Based on the heights above the Gunnison River and a regional rate of stream incision of about $0.15 \mathrm{~m} / \mathrm{ky}$, the lowest terrace remnant is $445-485 \mathrm{ka}$ and the highest terrace is $600-700 \mathrm{ka}$. The map unit ranges from about 8 to $15 \mathrm{~m}$ thick

Terrace alluvium 100 of the Colorado River (middle Pleistocene)-Alluvium deposited by the Colorado River that underlies terrace remnants between about 80-100 m above the river. The map unit consists mainly of well-sorted, rounded to well-rounded pebblecobble gravel containing less abundant boulders. Upstream from the junction with the Gunnison River, clasts consist mainly of quartzite, basaltic rocks, intermediate-composition volcanic rocks, fine-grained red micaceous sandstone, and fine-grained granitic rocks. Downstream from the confluence of the Colorado and Gunnison Rivers, clasts consist of similar clast rock types with the addition of intermediate-composition volcanic rocks carried by the Gunnison River from the San Juan Mountains to the south. Many clasts have thin $(1-2 \mathrm{~mm})$ carbonate coatings. All "oil shale" clasts of the Green River Formation in exposures are highly shattered or thoroughly weathered. The matrix consists of pale-brown (10YR 6/3) silty sand and sand, forming about $5-10 \%$ of the unit. Locally, gravels are overlain by 1-2 m of massive, light-yellowish-brown (10YR 6/3) silty fine sand and fine sand; at one terrace remnant located $0.4 \mathrm{~km}$ northwest of No Thoroughfare Canyon, this fine-grained deposit is at least $3 \mathrm{~m}$ thick. Several exposures display stage III carbonate (Gile and others, 1966). The map unit contains lenses of lightgray (10YR 7/2), well-sorted, cross-bedded, coarse to medium sand $25-50 \mathrm{~cm}$ thick. In places, the upper $25 \mathrm{~cm}$ of gravel contains abundant platy shale clasts derived from the Green River Formation. The map unit forms dissected and discontinuous terrace remnants that can be traced across the map area. Based on the height of this unit above the Colorado River and a regional rate of stream incision of about $0.15 \mathrm{~m} / \mathrm{ky}$, the terrace remnants of this unit may range from about 645 to about $685 \mathrm{ky}$. This map unit is equivalent to map unit Qt3 on adjacent Clifton quadrangle (Carrara, 2001). The map unit has been mined for gravel in the past on the Clifton quadrangle (Carrara, 2001). Unit Qt100 is commonly 3-6 m thick, and the maximum thickness is about $12 \mathrm{~m}$

Terrace alluvium 170 of the Colorado River (early Pleistocene)-Alluvium deposited by the Colorado River that underlies several terrace remnants about 163-175 m above the river. The map unit consists mainly of well-sorted, rounded and well-rounded pebblecobble gravel. Clasts consist mainly of quartzite, fine-grained micaceous red sandstone, fine-grained granitic rocks (many of which are disintergrated to grus), and basaltic rocks. Many clasts have thin carbonate coatings 1-3 mm thick. "Oil shale" clasts of the Green River Formation were not found and may have been too weathered to be recognized. The matrix consists of pale-brown (10YR 6/4 or 7/4) fine sand and silty fine sand, forming about $5-10 \%$ of the unit. In places, the clasts exposed on the terrace surface have rock varnish coatings. Locally, gravels are overlain by $1 \mathrm{~m}$ of light-brown (7.5YR $6 / 4$ ), massive, silty fine sand and fine sand displaying stage III carbonate (Gile and others, 1966). In places, the map unit contains lenses of light-olive-gray (5Y 6/2), well-sorted, cross-bedded, coarse to medium sand $10-30 \mathrm{~cm}$ thick. The map unit forms three isolated terrace remnants west of the Gunnison River in the south-central part of the map area. Based on the height of this unit above the modern rivers and a regional rate of stream incision of about $0.15 \mathrm{~m} / \mathrm{ky}$, the terrace remnants of this unit may range from about 1,085 to about $1,165 \mathrm{ka}$. The map unit is probably equivalent to map unit Qt4 on the adjacent Clifton quadrangle (Carrara, 2001). The map unit has a maximum thickness posits on pediment surfaces

Young fan-alluvium and debris-flow deposits (Holocene) - Chiefly well sorted silty sand and subordinate discontinuous lenses and layers of clast-supported gravel. Silty sand is generally greater than $1 \mathrm{~m}$ thick, but is also locally present in beds as thin as $2 \mathrm{~cm}$. Some 
of the silty sand may have been deposited as eolian sand, but much of it is probably reworked by water. Gravel layers are commonly $5-45 \mathrm{~cm}$ thick, and clasts range from 2-mm granules to boulders greater than $1 \mathrm{~m}$ in diameter near active stream channels. These clasts are rounded to subrounded and moderately to poorly sorted, and were derived largely from Mesozoic and Proterozoic units exposed in the highlands to the southwest on the Uncompahgre Plateau. The gravel was probably deposited by streams and locally by debris flows. Colors of the unit, where silty sand dominates, range from yellowish red (5YR 5/8) to reddish yellow (5YR 6/6). A high gravel content lends a gray color to the unit. There is little or no secondary carbonate on clasts and in the matrix. The map unit forms several fans on younger alluvium deposited by the Colorado River (Qalc1) and alluvium deposited by the Gunnison River (Qalg). The base of the map unit is as low as $1.5 \mathrm{~m}$ above the river. Exposed thickness of Qfy is about 1-5 m; maximum thickness is about $12 \mathrm{~m}$

Qac

Opwf

Qaso

Alluvium and colluvium, undivided (Holocene and late Pleistocene) - Predominantly a mix of alluvium, sheetwash, and debris-flow deposits. Extensive agricultural, industrial, and housing development in much of the map area has modified, covered, and obscured contacts between this unit and adjacent units. North of the Colorado River, the map unit consists of light-gray (10YR 7/2, $2.5 \mathrm{Y} 7 / 2$ ) and light-olive-gray (5Y 6/2), massive, fine sandy silt and clayey silt that forms a broad gentle slope with a gradient of about 6-7 $\mathrm{m} / \mathrm{km}$. Locally, the map unit contains scattered angular and subangular platey shale and sandstone pebbles derived from the Mancos Shale $(\mathrm{Km})$ and the overlying Mesaverde Group. The map unit also contains scattered sandstone boulders, as large as $1 \mathrm{~m}$ in diameter, derived from the Mesaverde Group. South of the Colorado River, the map unit consists of poorly exposed, very pale brown (10YR 7/3), and pale-brown (10YR $6 / 3$ ), unstratified to poorly stratified, fine sand, silty fine sand, and clayey silt containing scattered clasts. Clasts form 5-20\% of the deposit, and are chiefly rounded to wellrounded pebbles and cobbles of Colorado River origin that have been reworked from nearby terraces. Many clasts have thin carbonate coatings 2-5 mm thick. Locally, the map unit contains pebble-cobble gravel lenses 1-1.5 m thick consisting of rounded to well-rounded pebbles and cobbles of Colorado River origin. The matrix in the gravels consists of light-yellowish-brown (10YR 6/4) sand and silty sand. In places, the presence of desiccation cracks suggests that the map unit contains expansive clays that may cause stability problems for roads and buildings. The thickness of the map unit, based on U.S. Bureau of Reclamation well logs (Phillips, 1986), is about 3-5 m near the Colorado River and as much as $20 \mathrm{~m}$ farther from the river

Pediment deposit of Walker Field (late? Pleistocene)-Predominantly debris-flow and alluvial deposits from the Book Cliffs that underlie pediment surfaces (Whitney, 1981). The map unit forms a thin discontinuous deposit overlying the pediment surfaces in the northern part of the map area. Extensive agricultural, industrial, and housing development in the map area has modified, covered, and obscured contacts between this unit and adjacent units. The pediment surface is $5-15 \mathrm{~m}$ above surrounding areas. The map unit consists of clast- to matrix-supported, unsorted to poorly sorted, unstratified to poorly stratified, pebbly, cobble-boulder gravel. Clasts consist of angular to subrounded sandstone derived from the Mesaverde Group. The matrix consists of a pale-brown (10YR 6/3) silty sand and sand. The largest boulders are about $1 \mathrm{~m}$ in diameter. The map unit has a maximum thickness of about $3 \mathrm{~m}$

Old alluvial-slope deposit (late Pleistocene)-Chiefly layers and lenses of poorly sorted, matrix- and clast-supported gravel and well-sorted silty sand. The gravel clasts range in size from granules to boulders $1.5 \mathrm{~m}$ in diameter. These clasts are predominantly metamorphic and igneous rocks derived from Precambrian rocks and less abundant sandstone and limestone clasts derived from Mesozoic rocks to the south in the highlands of the Uncompahgre Plateau. The matrix of the gravel is silty sand. Gravel has light- to dark-gray colors from the clasts and a pink (5YR7/3-4) matrix. Gravelly zones may exceed $6 \mathrm{~m}$ in thickness, and silty sand beds are $0.2-6 \mathrm{~m}$ thick. Most clasts are subangular to subrounded, but some of the angularity appears to be related to weathering after deposition. The gravel layers are massive to poorly bedded, and local gravel forms discontinuous lenses in thick beds of silty sand. Zones of nonsorted to very poorly sorted bouldery deposits suggest deposition as debris flows; some gravel deposits are better sorted and were probably deposited by fluvial processes. In the upper $0.3 \mathrm{~m}$ of the unit, secondary calcium carbonate in the matrix and on clasts has stage II morphology; at a depth of 5-6 m, gravel is indurated by secondary calcium carbonate that has strong stage III morphology. The silty sand layers are generally massive and weakly bedded, and have colors that range from yellowish red (5YR5/8) to reddish yellow (5YR6/6). Where bedding is more distinct, the beds of silty sand are $0.1-0.5 \mathrm{~m}$ 
thick, and massive silty sand is locally as thick as $6 \mathrm{~m}$. The unit includes eolian sand and silt that probably has been reworked by stream and sheetwash processes. Unit Qaso locally overlies Colorado River gravel $(0 \mathrm{t} 30)$ near the bluffs on the south side of the Colorado River on the western side of the map area where it is exposed west of the mouth of No Thoroughfare Canyon. Exposed thickness of unit Qaso is at least $10 \mathrm{~m}$ Local gravel deposits (middle Pleistocene)-Poorly sorted, subrounded, clast- and matrixsupported pebble and cobble gravels that locally contain boulders as long as $2 \mathrm{~m}$. Unit Qlg was deposited by streams tributary to the southern side of the Colorado River. Clasts consist primarily of metamorphic and igneous Proterozoic rocks and secondarily of sedimentary rocks eroded from the highlands in the Uncompahgre Plateau, which is exposed in the adjacent Colorado National Monument quadrangle (Scott and others, 2001). Thin lenses of silty sand and scattered granules and pebbles are present locally in unit Qlg. In the upper $2 \mathrm{~m}$ of the unit, secondary calcium carbonate coats clasts. The matrix consists of yellowish-red (5YR5/6), pedogenic, calcium carbonate-rich (stage II) silty sand and granules. Unit QIg probably consists of remnants of stream-channel and debris-flow deposits that accumulated below the mouths of canyons southwest of the map area along the front of the Uncompahgre Plateau. Eroded remnants of the unit are preserved on hilltops about 55-79 $\mathrm{m}$ above modern intermittent tributary streams. Assuming an incision rate of about $0.15 \mathrm{~m} / \mathrm{ky}$ for the Colorado River and its tributary streams, unit Qlg was deposited between about 365 and $525 \mathrm{ka}$. Gravel locally fills channels as deep as $1 \mathrm{~m}$ that are cut in the underlying bedrock. At four localities in the western part of the map area, unit QIg overlies two Colorado River gravels (Qt60 and Qt100). The degree of weathering of clasts, as indicated by the angularity of Precambrian metamorphic and igneous clasts, is greater with age, and therefore is greater with height above stream level. Biotite-rich schist is particularly susceptible to both disaggregation and spheroidal weathering. Thin, unmapped veneers of Holocene eolian sand mantle of most of unit Qlg. Thickness of unit Qlg is as much as $6 \mathrm{~m}$

QIg/Qt30 Local gravel deposits over terrace alluvium 30 of the Colorado River (middle Pleistocene)Unit present west of the junction of the Colorado and Gunnison Rivers

Eolian and colluvial deposits-Wind-deposited silty sand, which chiefly mantles level to gently sloping surfaces, intertongues with colluvial deposits of silt, sand, and rock fragments and with sheet wash, which generally mantle valley sides and hill slopes

Qse

Eolian sand and sheetwash deposits (Holocene and late Pleistocene)-Chiefly silty very fine to fine sand that commonly contains scattered granules to cobbles from bedrock units exposed upslope. Unit Qse accumulated on gentle to moderate slopes with gradients between about $50 \mathrm{~m} / \mathrm{km}$ and $100 \mathrm{~m} / \mathrm{km}$. On steeper slopes near upslope bedrock outcrops, unit Qse is likely to contain significant amounts of colluvial clasts. Sheetwash deposits in unit Qse contain discontinuous layers and lenses of poorly sorted clasts. Colors of the unit range from yellowish red (5YR 5/8) to reddish yellow (5YR 6/6). Where wind and sheetwash erosion have winnowed out sand and finer sediment, a lag of granules, pebbles, and sparse cobbles covers the surface. Unit Qse is mainly found in southwestern part of the map area along the flank of the Uncompahgre Plateau. Maximum thickness of the map unit is about $5 \mathrm{~m}$

Qse/Qt30 Eolian sand and sheetwash deposits over terrace alluvium 30 of the Colorado River (Holocene to middle Pleistocene)-Unit present southwest of junction of Colorado and Gunnison Rivers

Colluvial deposits - Silt, sand, and rock fragments on valley sides and hill slopes that were mobilized, transported, and deposited by gravity Qlsy

Younger landslide deposits (latest Holocene)-Unit consists of two small landslide deposits along the south side of the Colorado River near the center of the map area, derived from the Mancos Shale $(\mathrm{Km})$, which contains expansive clays and bentonite layers. The map unit consists of unstratified, pale-brown (10YR 6/3) sandy silt, silt, clayey silt, and silty clay. The map unit consists largely of rotational types of landslides as defined by Varnes (1978). These landslides should be considered active. In the 1980's, reactivation of the eastern landslide resulted in severe damage and forced the abandonment of several homes that were only a few years old at the time (Jochim and others, 1988). Small landslides are likely to form elsewhere along the south bluff of the Colorado River. Roads and structures are subject to landslide hazards, especially those that are close to river bluffs where excess irrigation or lawn water has been applied or the river has undercut the bluffs. Along active cut banks, the Colorado River probably removed evidence of similar landslide deposits. Also in this map area, young landslides too small to map have damaged a sewage treatment plant and an irrigation pump station near the eastern part of The Redlands. The thickness of unit Qlsy is about $20 \mathrm{~m}$ 

Lithologies and colors of colluvium reflect the bedrock and surficial units from which the colluvium was derived. Unit Qc is commonly formed at the base of cliffs or steep hills. The map unit locally includes sheetwash, debris-flow, and landslide deposits. Colluvium derived from the Morrison Formation contains expansive clays. Clasts are angular to subangular and are as large as $2 \mathrm{~m}$ in diameter. Secondary carbonate coatings on clasts in the upper part of the unit are thin and have stage I morphology. Maximum thickness is about $5 \mathrm{~m}$ slide, rock-slide, debris-slump, rock-slump, slump-earth-flow, earth-flow, debris-flow, and complex landslide deposits as defined by Varnes (1978). The map unit consists of mainly unsorted and unstratified rock debris characterized by hummocky topography. The sizes and lithologies of the clasts and the grain-size distributions and colors of the matrices of these deposits reflect those of the displaced bedrock units and surficial deposits. Many of the landslides in the southwestern and southern parts of the map area formed on unstable slopes that are underlain by the Brushy Basin Member of the Morrison Formation $(\mathrm{Jmb})$ that contains abundant smectitic expansive clays. These landslide deposits include debris from the Brushy Basin Member of the Morrison Formation ( $\mathrm{Jmb}$ ), the Burro Canyon Formation $(\mathrm{Kb})$, and the Dakota Formation $(\mathrm{Kd})$. Some of these landslides lack distinctive landforms such as crescentic headwall scarps and lobate toes, but still have hummocky surfaces. Rejuvenated parts of these landslides may have crescentic headwall scarps. However, no headwall scarp remains along the highest part of the large $(2.5 \mathrm{~km}$ by 3.5 $\mathrm{km}$ ) older landslide deposit exposed along the upper part of Little Park Road because all stratigraphic material younger than the Brushy Basin Member has already slid downhill. Where Little Park Road descends from the landslide deposits onto the yet-intact dipslope of the Dakota and Burro Canyon Formations, numerous homes have been built. At the base of the dipslope, several homes were built on Burro Canyon Formation that dips into the hill, typical of incipient rotated landslide blocks, rather than parallel to the dip slope. Extensive watering of lawns on the dip slope of Little Park Road may increase the probability of activating a landslide and should be avoided. The older landslide deposits between the Gunnison River and Horse Point south of the river have morphologies that suggest that the oldest parts of the deposits are closest to the river and the youngest are closest to Horse Point. The river appears to be eroding these deposits as they are moved downward in a conveyor-belt fashion. Deposits derived from the Dakota and the Burro Canyon Formations ( $\mathrm{Kd}$ and $\mathrm{Kb}$ ) contain blocks of rock as long as $6 \mathrm{~m}$. Landslide deposits are prone to continued movement or reactivation due to natural as well as human-induced processes, such as excavations and irrigation. The exposed thickness of the map unit is at least $65 \mathrm{~m}$ and may be as great as $85 \mathrm{~m}$

\section{BEDROCK UNITS}

Mancos Shale (Upper Cretaceous; Campanian to Cenomanian)-Chiefly a medium-darkgray, dark-gray, brownish-gray, and brownish-black fissile shale that weathers light gray.

The upper part of the Mancos is locally exposed in the northern part of the map area. It is a massive and monotonous, fissile shale that contains expansive smectitic clays, particularly in bentonite beds.

The lower part of the Mancos was mapped above the base of the nearly continuous dark fissile shale that overlies the uppermost prominent set of thin sandstone beds and carbonaceous interbeds of the Dakota Formation (Kd). The lowermost Mancos also contains sparse interbeds of thinly laminated, fissile-weathering, partly bioturbated, calcareous and carbonaceous siltstone and sandy siltstone, which contain sparse interbeds of sandstone. The sandstone typically forms beds $<10 \mathrm{~cm}$ thick and is very fine to fine grained, well sorted, and calcareous. The beds commonly exhibit ripple lamination, including both oscillation and combined flow, and locally display hummocky cross lamination. Several light-gray to yellowish-gray thin stringers and beds of volcanic ash are altered to nearly pure highly expansive bentonite and are as much as $20 \mathrm{~cm}$ thick. The lowermost Mancos is fossiliferous, but pelecypods and cephalopods are generally only found in recent roadcuts or excavations where disaggregation due to rapid weathering has not occurred. Marine trace fossil burrows are common. These lower Mancos strata are equivalent to the Tununk Member of the Mancos Shale recognized in Utah (Fouch and others, 1983; Cole, 1987).

The unit is prone to failure (landsliding and debris flows) where exposed on steep slopes, such as along the bluffs along the south side of the Colorado River. The map unit 
may have moderate to high swelling potential due to the presence of expansive clays, and it contains sulfate minerals (largely gypsum and thenardite) that are corrosive to conventional concrete and metal pipes. Unimproved roads are virtually impassable when wet.

The age of the Mancos Shale in the Grand Junction area has been assigned to the Campanian to Cenomanian Ages (Young, 1959). The map unit reaches a thickness in excess of 1,370 $\mathrm{m}$ in the western Colorado region (Cole and others, 1999; Cole and Moore, 1994), but lack of exposures of the middle part of the Mancos does not permit a precise estimate of the thickness of the map unit here

Dakota Formation (Upper and Lower? Cretaceous; Cenomanian and Albian?) - Consists of about $20-50 \%$ sandstone, 40-60\% mudstone, 5-20\% conglomerate, and less than 5\% impure coal, similar to exposures in the adjacent Colorado National Monument quadrangle (Scott and others, 2001). There are four parts in the map unit: from top to bottom these are an interbedded sandstone and shale part, a sandstone part, a mudstone part, and a conglomeratic part.

The interbedded sandstone and shale part is dominantly shale or shaley mudstone, thin sandstone beds, and stringers of coal. This upper part is gradational with the overlying Mancos Shale $(\mathrm{Km})$. Shale in the uppermost part of the Dakota is interbedded with channel-form sandstones, is usually much less carbonaceous than elsewhere in the unit, and consists of brownish-gray to greenish-gray, thinly laminated, fissile-weathering, slightly carbonaceous, slightly calcareous siltstone and clayey siltstone, which are bioturbated by roots and indistinct burrows.

The sandstone part also contains subordinate conglomerate, stringers of coal, and minor mudstone. Sandstone is commonly light gray to pale yellowish orange, white, and pinkish gray or very pale orange, forms thick to very thin beds, and is very fine to fine grained, moderately to poorly sorted, bioturbated, locally argillaceous, and slightly calcareous to noncalcareous. Thicker sandstone bodies $(1-5 \mathrm{~m})$ have channel-form geometries and associated scour surfaces and lag gravels, which include blebs of mudstone and clasts of chert, quartz, and rock fragments. Stratification consists of smallto medium-scale trough and tabular-tangential cross stratification, symmetric and asymmetric ripple lamination, horizontal lamination, and contorted bedding.

The mudstone part is chiefly mudstone and subordinate impure coal. Mudstone consists of brownish-gray to grayish-black, medium to thinly laminated (platy to fissile weathering), carbonaceous to very carbonaceous, bioturbated, silty claystone and clayey siltstone, containing thin beds and lenses of very fine to fine grained, quartz-cemented sandstone and white altered volcanic ash. Fossil plant fragments are very common. Impure coal seams and stringers, ranging in thickness from 5 to $40 \mathrm{~cm}$, are present within the carbonaceous mudstone.

Although the conglomeratic part is capped by sandstone, conglomerate predominates. The conglomerate part contains clasts that range in size from fine sand to pebbles and is typically light gray to white or pinkish gray, poor to moderately sorted, slightly argillaceous, slightly calcareous to noncalcareous, and friable. Also,the conglomerate part has medium to very thick beds and blocky and slabby weathering and contains minor sandstone interbeds. Clasts are commonly graded and consist of mudchips, chert, quartz, and rock fragments. Stratification in conglomerate is generally indistinct, consisting of poorly defined low-angle scour surfaces.

In the map unit, bioturbation is common and includes fossil plant roots and burrows. Burrows in the upper Dakota are marginal marine in origin, whereas those in the lower Dakota are terrestrial. Sandstone and conglomerate intervals form prominent, resistant ledges and ridges, whereas mudstone and interbedded sandstone and shale intervals generally form slopes. The Dakota Formation forms the uppermost unit of the prominent dipslope that dominates the area south of the Gunnison and Colorado Rivers because the Mancos Shale $(\mathrm{Km})$ has largely been eroded as the Colorado River migrated northward with time. The Dakota Formation rests disconformably(?) on the underlying Burro Canyon Formation (Kb). The base of the Dakota Formation was arbitrarily defined during mapping as the base of the lowest carbonaceous mudstone above the Burro Canyon Formation $(\mathrm{Kb})$. The lowest thick sandstone interval above the carbonaceous mudstone of the Dakota Formation commonly has been bleached white in contrast to light yellow and orange colors elsewhere. According to William A. Cobban (U.S. Geological Survey, oral commun., 1999), the upper part of the Dakota contains Cenomanian Age fauna near Delta, Colo., $60 \mathrm{~km}$ to the southeast of the map area, and the lower Dakota is probably Albian Age near the map area.

A number of residential subdivisions in The Redlands area on the dipslope of the Dakota Sandstone display evidence of unstable foundations. Cracked streets, unevenly 
closing garage doors, and slumping slopes in areas of heavily watered lawns are commonly observed characteristics. Apparently the clay-rich layers in the Dakota become unstable when saturated with water. 1999)

The total map unit thickness is estimated to be about 45-50 m (Cole and others,

Burro Canyon Formation (Lower Cretaceous; Albian and Aptian)-Consists of about 20-60\% sandstone, 40-80\% mudstone, and 0-15\% conglomerate. In most localities, the upper part is dominated by mudstone and forms slopes, whereas the lower third to two-thirds of the unit is dominated by sandstone and forms cliffs or steep hillsides.

Mudstone is typically medium to thinly laminated (platy to fissile weathering), slightly bentonitic to nonbentonitic, slightly calcareous, and usually bioturbated (roots and some burrows). Thin (less than $1 \mathrm{~m}$ thick) paleosol horizons that are composed of white to light-gray, earthy carbonate nodules are locally interbedded with mudstone in the upper Burro Canyon.

Laterally discontinuous sandstone occurs in channel-form bodies and is typically white to yellowish gray, thick bedded to thinly laminated, blocky to flaggy weathering, fine to medium grained, moderately sorted, and quartz cemented. Locally, the sandstone includes large amounts of petrified wood. Sandstone sequences contain numerous laterally and vertically amalgamated scour surfaces accentuated by thin lag gravels, which include clasts of green mudstone, chert, quartz, petrified wood, and dinosaur bone. Medium-scale trough and tabular-planar cross stratification is common in sandstone beds; contorted bedding and bioturbation (roots and elongate vertical burrows) may also occur. Mudstone consists of pale-red, pale-olive to yellowish-green siltstone, clayey siltstone and silty claystone and ranges from thin interbeds within the channel-form sandstone bodies to discrete sequences more than $10 \mathrm{~m}$ thick. Locally, conglomerate beds are as much as $3 \mathrm{~m}$ thick near the base of the map unit; they are commonly yellowish gray, moderately sorted, well rounded, massive to poorly bedded, channel form, and discontinuous laterally. The conglomerate clasts consist largely of chert and quartz pebbles but include minor petrified wood and dinosaur bone.

The base of the Burro Canyon Formation rests on the K-1 (basal Cretaceous) unconformity (Peterson, 1994; Peterson and Turner, 1998) above the Brushy Basin Member of the Morrison Formation ( $\mathrm{Jmb}$ ), but that unconformity was impractical to map because it is defined by microfossils and a poorly exposed paleosol. Therefore, the base of the Burro Canyon was arbitrarily defined as the lowest thick sandstone or conglomerate bed above the mudstone of the Brushy Basin Member ( $\mathrm{Jmb}$ ). As a result, an undetermined interval of lowermost Burro Canyon mudstones above the unconformity may have been included in the Brushy Basin (Aubrey, 1998). Because of the discontinuous and lenticular character of the sandstone and conglomerate beds in the Burro Canyon, the basal contact and the thickness of the rock unit differ from place to place.

The Burro Canyon Formation is of Albian and Aptian Ages according to palynological evidence (Craig, 1981). The thickness of the map unit is about $60 \mathrm{~m}$ at the prominent point $0.6 \mathrm{~km}$ east of the west boundary and $2.5 \mathrm{~km}$ north of the southern boundary of the map area; this is considerably thicker than the $30 \mathrm{~m}$ measured at Black Ridge in the Colorado National Monument quadrangle (Cole and others, 1999)

Morrison Formation (Upper Jurassic)-Consists of three members from top to bottom: the Brushy Basin Member, the Salt Wash Member, and the Tidwell Member. The Morrison Formation is about $170 \mathrm{~m}$ thick at the point $0.6 \mathrm{~km}$ east of the west boundary and 2.5 $\mathrm{km}$ north of the southern boundary of the map area, but individual members do not have laterally consistent thicknesses. Contacts between the Morrison Formation members were located at horizons that could be readily followed on aerial photographs and easily located in the field rather than horizons defined by micropaleontological or ${ }^{40} \mathrm{Ar} / 39 \mathrm{Ar}$ isotopic dating evidence

Brushy Basin Member (Tithonian and Kimmeridgian) - Consists of mudstone (85-95\%), sandstone (5-15\%), and sparse limestone.

About $75 \%$ of the mudstone consists of variegated grayish-yellow-green, greenishgray, yellowish-gray, brownish-gray, grayish-red, greenish-yellow, and grayish-orangepink, medium to thinly laminated (platy to fissile weathering), mottled, bioturbated (?), earthy, bentonitic, slightly calcareous, clay-rich siltstone, mudstone, and silty mudstone. The silty mudstone contains thin interbeds of very fine grained, well-sorted, bioturbated sandstone and gray, nodular, finely crystalline limestone (possible soil nodules?). Nodular barite and dinosaur bone are present. Bentonitic mudstone expands and dries to form a popcorn-like weathered appearance. The remaining $25 \%$ of the mudstone that is not conspicuously bentonitic consists of variegated pale-olive, reddish-brown, greenish-gray, 
grayish-yellow-green, yellowish-gray, yellowish-orange, and grayish-red, thickly to thinly laminated (flaggy to fissile weathering), partly bioturbated, slightly calcareous to noncalcareous, siltstone, sandy siltstone, and silty mudstone. The silty mudstone also contains thin interbeds of very fine grained sandstone.

Sandstone sequences are most common in the lowermost and uppermost Brushy Basin Member. They typically form channels and range in thickness from less than $1 \mathrm{~m}$ to more than $4 \mathrm{~m}$. Sandstone is typically greenish yellow to dusky yellow green and greenish gray, medium bedded to thickly laminated, slabby to flaggy weathering, very fine to coarse grained, poorly to moderately sorted, slightly calcareous to noncalcareous, locally bioturbated by burrows and roots, and contorted by soft-sediment deformation. The thicker channel sequences usually have small-scale trough cross stratification and scour surfaces accentuated by pebble-size mudchips and chert and quartz granules, whereas thinner sandstone beds are commonly bioturbated.

Limestone is light gray, thinly to medium bedded and similar to the limestone in the underlying Salt Wash and Tidwell Members.

Because of its susceptibility to mass wasting, particularly landsliding, the Brushy Basin Member is relatively poorly exposed. Where exposed, it forms slopes. The Brushy Basin Member of the Morrison Formation rests disconformably above the Salt Wash Member (unnamed unconformity; R.G. Young, oral commun., Grand Junction, Colo., 1999). The contact between the two members was defined as the top of the highest thick sandstone of the Salt Wash below the mudstones of the Brushy Basin. Single-crystal, ${ }^{40 \mathrm{Ar} / 39} \mathrm{Ar}$ ages of feldspars from the Brushy Basin Member indicate that the age of the member is probably Tithonian and Kimmeridgian (Kowallis and others, 1991; Kowallis and others, 1998). The Brushy Basin Member is about $95 \mathrm{~m}$ thick at the prominent point $0.6 \mathrm{~km}$ east of the west boundary and $2.5 \mathrm{~km}$ north of the southern boundary of the map area near Little Park Road (Cole and others, 1999)

Salt Wash Member (Kimmeridgian) - Consists of sandstone (30-80\%), mudstone (20-70\%), and sparse limestone.

Sandstone is very pale orange, yellowish gray, and light gray, fine to medium grained, moderately sorted, slightly calcareous, and friable; it typically forms channelform beds that range from 1 to $5 \mathrm{~m}$ thick, are very thinly to very thickly bedded, and are slabby to blocky weathering. Thicker sand bodies commonly exhibit small- to large-scale trough, tabular-tangential, and sigmoidal cross bedding, as well as scour surfaces accentuated by granule- to pebble-size lag gravels composed of red and green mudstone, quartz, and chert. Elongate, narrow burrows are common near the tops of the thicker sand bodies.

Mudstone intervals consist of pale-brown to greenish-yellow, grayish-red, and yellowish-gray, silty claystone, siltstone, sandy siltstone, and mudstone. Mudstone forms 0.1- to 1-m-thick interbeds between sandstone channels, but can also form sequences as thick as $15 \mathrm{~m}$ where sandstone channels are poorly developed. These mudstone bodies are commonly thickly to thinly laminated, flaggy to fissile weathering, slightly calcareous, slightly bentonitic, and commonly bioturbated by insect burrows and plant roots. Wellcemented, mottled mudstone intervals weather to form nodules. Thicker mudstone sequences commonly have thin interbeds and lenses of very fine to fine-grained, wellsorted sandstone.

Minor limestone is similar to limestone in the underlying Tidwell Member; it is typically light gray to light olive gray, slightly sandy to silty, mottled, bioturbated, finely crystalline and is slightly fossiliferous containing ostracodes and charophytes. It has the mud-supported fabrics of carbonate mudstone and wackestone. Limestone beds are laterally discontinuous, are less than $0.3 \mathrm{~m}$ thick, and form nodules within mudstone.

The Salt Wash Member is a cliff- and ledge-forming unit in contrast to the slopeforming Brushy Basin and Tidwell Members of the Morrison Formation. The base of the Salt Wash Member was defined during mapping as the top of the uppermost major limestone bed of the Tidwell Member (Jmt) below the thick sandstone beds of the Salt Wash Member. The Salt Wash Member exhibits considerable lateral variation in thickness and lithology within the quadrangle. Exposures are limited to the southwestern part of the map area. As the overlying Brushy Basin Member ( $\mathrm{Jmb}$ ) was assigned to the Tithonian and Kimmeridgian Ages (Kowallis and others, 1991; Kowallis and others, 1998) and the underlying Tidwell Member (Jmt) was assigned to the Kimmeridgian and latest Oxfordian Ages (Kowallis and others, 1998), the Salt Wash is restricted to the Kimmeridgian. On the west side of the map area, the map unit is about $50 \mathrm{~m}$ thick but thins to only a few meters thick and may be locally absent south of the prominent point near Little Park Road. Farther to the southeast, the map unit thickens to as much as 30 $\mathrm{m}$ 

proportions of interbedded mudstone (50-70\%), sandstone (10-40\%), and limestone (520\%) (Cole and others, 1999).

Mudstone typically consists of grayish-red to grayish-yellow-green sequences of siltstone, sandy siltstone, silty claystone, and mudstone, ranging in thickness from a few centimeters to more than $4 \mathrm{~m}$. These sequences are commonly very thin bedded to thinly laminated, slabby to fissile weathering, mottled, bioturbated by roots and burrows, and slightly calcareous to very calcareous. Calcareous mudstone intervals weather to form nodules.

Sandstone is light gray to light greenish gray, very thinly bedded to very thickly bedded, slabby to blocky weathering, fine to medium grained, moderately to well sorted, calcareous, and locally bioturbated by roots and burrows. Sedimentary structures in sandstone include horizontal lamination, discontinuous wispy bedding-parallel lamination, wavy bedding-parallel hummocky lamination, small- to medium-scale trough and tabulartangential cross stratification, and asymmetric current and symmetric wave ripple stratification. Sandstone beds range in thickness from less than $1 \mathrm{~cm}$ to about $2 \mathrm{~m}$ and exhibit both tabular and channel-form cross-sectional geometries. The lowermost sandstone bed that defines the base of the Tidwell is informally called " $\mathrm{A}$ " bed (Pipiringos and O'Sullivan, 1978), rests on the J-5 unconformity, (Peterson, 1994), and is continuous throughout the quadrangle. The "A" bed, which is approximately $1 \mathrm{~m}$ thick, has a basal lag composed of medium-grained sand to granule composed of chert and lithic grains; similar granule lenses also occur within this bed.

Limestone is typically light gray to light olive gray, dense, hard, slightly sandy or silty, very fine to finely crystalline, and resistant to weathering forming slabby to blocky exposures. Most limestone is mottled and bioturbated by burrows, although stromatolitic lamination produced by algal (cyanobacteria?) growth and oncoids is locally present. Fossils are sparse and consist of ostracodes, charophytes, and very small gastropods. Petrographically, the Tidwell limestones are classified as carbonate mudstone and packstone (Dunham, 1962). Limestone beds range in thickness from several centimeters to about $1 \mathrm{~m}$ and are most abundant in the upper half of the Tidwell. Between two and seven limestone beds are present.

Within the Tidwell Member, the lithologic character of mudstone, sandstone, and limestone significantly changes laterally. This slope-forming unit rests on the Wanakah Formation (Jw), which is below the J-5 unconformity (Peterson, 1994), whereas the upper contact with the overlying Salt Wash Member of the Morrison Formation is transitional. For mapping purposes, the upper contact of the Tidwell Member was placed at the base of the thick sandstone intervals of the Salt Wash Member. These sandstone intervals are discontinuous and lenticular, and therefore this contact and thicknesses of adjacent units are irregular. Anderson and Lucas (1998) considered the strata below the Salt Wash Member southwest of the map area to be the Summerville Formation because of the presence of thin, parallel-bedded gypsiferous strata typical of the Summerville Formation there. The lack of this distinctive lithology in the map unit indicates that the Tidwell Member of the Morrison Formation nomenclature should be retained in the map area. Also, most of the Summerville is truncated beneath the J-5 unconformity (O'Sullivan 1991). O'Sullivan (1992) indicated that the Tidwell is Kimmeridgian Age, but subsequent $40 \mathrm{Ar} / 39 \mathrm{Ar}$ sanidine dating suggest that the Tidwell is Kimmeridgian to latest Oxfordian (Kowallis and others, 1998). The Tidwell Member ranges from about 30 to $45 \mathrm{~m}$ thick where exposed in the southwestern part of the map area

Wanakah Formation (Middle Jurassic; Callovian) - Consists of interstratified mudstone (70$80 \%)$, sandstone and silty sandstone (5-15\%), impure limestone (0-5\%), and traces of volcanic ash and gypsum.

Mudstone consists of reddish-brown, grayish-red-purple, yellowish-brown, paleolive, and greenish-gray siltstone, sandy siltstone, and mudstone. The greenish-gray mudstone occurs chiefly in the upper half of the unit. Mudstone intervals are medium to thinly laminated and are platy, fissile and nodular weathering, mottled, bioturbated by burrows and roots, slightly calcareous, and nonbentonitic. Sandstone forms very thin to thin, slabby weathering interbeds and discontinuous lenses in the mudstone sequence and is typically light brown to light gray, very fine to fine grained, moderately to well sorted, silty, bioturbated, and calcareous.

The sandstone displays discontinuous horizontal lamination and asymmetric ripple lamination, and the limestone forms gray to grayish-red and light-gray, sandy to silty, bioturbated, discontinuous nodules that are commonly less than $5 \mathrm{~cm}$ in diameter. 
Radiometric analysis of the formation shows a large positive gamma-ray anomaly, which is associated with several light-grayish-green, volcanic ash laminae less than $1 \mathrm{~cm}$ thick, approximately $5 \mathrm{~m}$ above the base of the unit (Cole and others, 1999). This interval and adjacent layers contain expansive clay that is associated with damaged road surfaces. The Wanakah is a slope-forming unit.

The Wanakah is truncated by the J-5 unconformity (Pipiringos and O'Sullivan, 1978), which shows minimal erosional relief throughout the quadrangle. Beneath this unconformity, the upper several meters of the Wanakah have numerous well-developed root traces. The base of the Wanakah Formation is defined at the base of the red mudstone that rests on the very pale orange to very light gray sandstone beds of the upper informal "board beds" unit of the Entrada Formation. The Wanakah Formation was previously called the Summerville Formation in Colorado National Monument (Lohman, 1963, 1981). Although stratigraphic correlations by O'Sullivan (1980, 1992) suggest that the Summerville does not exist in western Colorado, more recent work of Anderson and Lucas (1998) proposed that the name Summerville Formation is appropriate for strata below the Salt Wash Member south and west of the map area. Whether the Summerville Formation as defined by Anderson and Lucas includes the Wanakah is unclear, but in the map area the term Wanakah is retained. The base of the Wanakah Formation is readily recognized in the field or on aerial photographs because of the distinctive red color of the lower part of the map unit. The Wanakah is assigned to the Callovian Age (O'Sullivan, 1992; Peterson, 1994). The map unit is $10 \mathrm{~m}$ thick where exposed in the southwestern part of the map area

Entrada Formation (Middle Jurassic; Callovian) - Consists of two parts, an upper informal unit locally called the "board beds" and the lower Slick Rock Member

"Board beds" unit-Consists of interbedded sandstone (60-70\%) and mudstone (30-40\%). Sandstone is very pale orange to very light gray, white, and pinkish gray, thin to thick bedded, slabby to blocky weathering, very fine to fine grained, moderately to well sorted, intensely mottled by bioturbation, and calcareous. Internal stratification is rare and consists of discontinuous, wispy horizontal lamination and small-scale sets of tabulartangential cross lamination of grain flow and wind ripple. Mudstone consists of reddishbrown to grayish-red, thickly to thinly laminated, flaggy to fissile weathering, siltstone and sandy siltstone, which is typically bioturbated. The base of the unit is defined at the top of the orange-pink, cross-bedded Slick Rock Member (Jes) of the Entrada.

The prominent white cap of the "board beds" unit above the Slick Rock Member differs significantly from the Moab Member of the Entrada Sandstone that is present southwest of the map area. Therefore, the stratigraphic nomenclature of Lohman $(1963,1981)$ for this unit is not retained in this report, and an informal name "board beds" unit is accepted here following O'Sullivan and Pipiringos (1983) until further stratigraphic studies are performed. The thickness of the "board beds" unit ranges from about 10 to $15 \mathrm{~m}$ where exposed in the southwestern part of the map area

Slick Rock Member-Consists almost entirely (99\%) of sandstone, which is orange pink to pale reddish orange, very thinly to very thickly bedded, slabby to blocky weathering, very fine to fine grained, moderately to well sorted, commonly mottled by bioturbation, calcareous, and weakly cemented. Stratification, where present, consists of small- to large-scale sets of trough, tabular-tangential, tabular-planar, and wedge-planar cross stratification, as well as discontinuous, wispy horizontal lamination. Cross-strata sets are mainly composed of wind-ripple lamination; grain-flow lamination is rare. Bioturbation increases upward and is commonly associated with first-order bounding surfaces. The member commonly forms a conspicuous rounded bench or cliff and rests on the reddishorange, thinly bedded sandstone of the Kayenta Formation. The Slick Rock Member of the Entrada Formation rests on the J-2 unconformity (Pipiringos and O'Sullivan, 1978; O'Sullivan and Pipiringos, 1983); erosional relief on the J-2 unconformity is as much as 3 m. The Slick Rock Member is Callovian Age (Peterson, 1988a). The thickness of the Slick Rock Member is about $30 \mathrm{~m}$ in the southwestern part of the map area

Kayenta Formation (Lower Jurassic; Pliensbachian and Sinemurian) - Consists of sandstone (80-90\%), conglomerate (0-10\%), and mudstone (0-10\%).

Sandstone is present throughout the Kayenta, whereas conglomerate and mudstone are found mainly in the upper half. Sandstone is typically reddish orange, grayish orange pink, light greenish gray, or white, fine to medium grained, moderately to well sorted, and cemented by a mixture of carbonate and quartz; it forms thin to very thin beds and slabby beds. Sandstone sequences in the Kayenta contain numerous amalgamated scour surfaces that commonly have lag gravels consisting of mudstone clasts. 
Conglomerate forms channel-form sequences composed of granule- to cobble-size clasts of reddish-orange mudstone in a matrix of medium-grained, moderately sorted, light-greenish-gray sandstone; clasts are typically graded.

Mudstone consists of reddish-brown to grayish-red, thinly laminated, fissileweathering, moderately to well-sorted siltstone and sandy siltstone; mudstone may be locally bioturbated.

Stratification is well developed in the Kayenta Formation and consists of small- to medium-scale sets of low-angle, even-parallel lamination, tabular-tangential cross stratification, and trough cross stratification; streaming and parting lineations are also common. The Kayenta commonly forms resistant ledges above the cliff-forming Wingate Sandstone (Jwg), but also forms cliffs in several areas. The base of the Kayenta is marked by the sharp break from small- to medium-scale cross beds of siliceously cemented sandstone and mudstone to the more massive, large-scale sets of cross stratification of the sandstone of the Wingate Formation. The Kayenta was tentatively assigned to Pliensbachian and Sinemurian Ages by Peterson and Pipiringos (1979), then restricted by Peterson (1988b) to Pliensbachian and Sinemurian Ages, and most recently further restricted by Peterson (1994) to Pliensbachian. The Kayenta Formation is about $25 \mathrm{~m}$ thick in exposures in the southwestern part of the map area sandstone and about 5\% mudstone.

The sandstone is typically orange pink to reddish orange, thin to very thickly bedded, slabby to blocky weathering, very fine to fine grained, moderately to well sorted, calcareous, well stratified, and partly mottled and bioturbated by roots and burrows. Stratification, when present, consists of small- to very large scale sets of evenparallel horizontal lamination, discontinuous even-parallel lamination, tabular-tangential cross stratification, tabular-planar cross stratification, wedge-planar cross stratification, and trough cross stratification. Wind-ripple lamination dominates the horizontal stratification sets, whereas wind-ripple lamination and grain-flow lamination characterize most largescale sets of cross stratification.

Mudstone is interbedded with siltstone and sandy siltstone, which are typically light brown to light reddish brown and reddish brown, thickly to thinly laminated, flaggy to fissile weathering, and generally mottled and bioturbated by roots(?). Stratification in mudstone is rare, usually consisting of discontinuous horizontal lamination, wispy lamination, and sparse current-ripple lamination.

The Wingate Sandstone is the major cliff-forming unit in Colorado National Monument in the southwestern part of the map area. The Wingate has been assigned to the Hettangian Age based on dinosaur fossils (Padian, 1989), but more recently to Pliensbachian to Hettangian Ages by Peterson (1994). The thickness of the map unit is about $100 \mathrm{~m}$

Chinle Formation (Upper Triassic) - Shown in cross section only. Consists of interbedded reddish-brown to reddish-orange and grayish-purple mudstone, sandstone, sandy conglomerate, and limestone. The map unit is about $30 \mathrm{~m}$ thick in the Colorado National Monument quadrangle (Cole and others, 1999) Shown in cross section only. For more detailed description see Scott and others (2001)

\section{STRUCTURE AND TECTONICS}

The structural geology of the Grand Junction quadrangle is deceptively simple. A large regional monocline dips northeast throughout the map area to form the northeastern flank of the Uncompahgre Plateau. Laramide compression probably formed the monoclinal structure (Hunt, 1956; Lohman, 1965; Stone, 1977; Miller and others, 1992; Davis, 1999), although no direct evidence has been found to determine the age of deformation of the Uncompahgre uplift (Scott and others, 2001). Dips in this monocline range from $9^{\circ}$ to $15^{\circ}$ in Jurassic strata in the southwestern part of the map area to about $4^{\circ}$ in Mancos Shale in the northeastern part of Grand Valley. Between Horse Point and the Gunnison River, two narrow, northwest-trending struc- tures are superimposed on the large regional monocline. The largest and most laterally persistent structure forms an asymmetric graben at its southeastern part but forms a 60-m-wide, southwest-dipping monocline at its northwestern end. The southeastern part consists of a 60-m-wide fault block of Burro Canyon Formation that dips southwest at greater than $50^{\circ}$ and is bounded by normal faults that separate the panel from the regional monocline that has more gentle dips to the northeast. Both the faulted block and the monocline create down-to-the-southwest stratigraphic offsets of about $20 \mathrm{~m}$ and $15 \mathrm{~m}$, respectively. Probably, these structures have been formed by a blind, northeast-dipping high-angle reverse fault that dies out toward the northwest (section A-A'). Another narrower southwest-dipping monocline deforms the overall monocline $2 \mathrm{~km}$ 
Table 4. Map units susceptible to geologic hazards in the Grand Junction quadrangle.

\begin{tabular}{|c|c|c|c|c|c|}
\hline Mass Wasting ${ }^{1}$ & Gullying & Piping $^{2}$ & \multicolumn{2}{|c|}{ Expansive Soils } & Flooding \\
\hline Olso & $\mathrm{Oa}$ & $\mathrm{Oa}$ & Qac & Qc & Qalc1 \\
\hline Qlsy & Qac & Qac & Qlso & $\mathrm{Km}$ & Qalc2 \\
\hline $\mathrm{Km}$ & $\mathrm{Km}$ & Qse & $\mathrm{Kb}$ & $\mathrm{Jmb}$ & Qalg \\
\hline $\begin{array}{l}\text { Kd } \\
\text { Jmb }\end{array}$ & & & Jw & Olsy & Qa \\
\hline
\end{tabular}

1'Includes earth flows, earth slumps, debris flows, debris slumps, rock-block slides, translational slides, rockfalls, and complex landslides.

2Defined as erosion by percolating water resulting in the formation of tunnels (pipes) through which fine-grained material is removed.

northeast of Horse Point and probably also overlies a concealed northeast-dipping high-angle reverse fault. The faulted panel structure has a geometry similar to that of the Glade Park fault mapped in the Glade Park 7.5' quadrangle (southwest of the map area) where it crosses the Little Park Road (Scott and others, 2001). For a more thorough discussion of the more regional aspects of the structures and tectonism of the area read the "Structure and Tectonics" part of the text for the map of the Colorado National Monument and adjacent areas (Scott and others, 2001).

\section{GEOLOGIC HAZARDS}

Various geologic hazards exist in the Grand Junction quadrangle, including landslides, erosional processes such as gullying and piping, expansive soils, and flooding. These hazards are commonly associated with specific geologic units (table 4).

\section{LANDSLIDES}

As used in this report, landslide is a general term that includes a wide variety of mass movement landforms and processes involving the slow to rapid downslope transport of surficial materials and bedrock blocks by gravity. This definition includes various types of flows, slumps, slides, topples, and combinations thereof.

Active landsliding (younger landslide deposits, Olsy) is found along the bluffs on the south bank of the Colorado River and has caused damage to roads and structures in the area. Many of these landslide deposits, which consist primarily of small rotational landslides and topples, are too small to show at the scale of this map. Also, many younger landslide deposits are removed by erosion of river banks soon after they form. Two small landslide deposits derived from the Mancos Shale $(\mathrm{Km})$ are shown near the center of the map, along the south side of the Colorado River. Reactivation of the eastern of the two landslides in the 1980's resulted in severe damage and forced the abandonment of several new homes (Jochim and others, 1988). On the eastern side of the adjoining Colorado National Monument quadrangle, $0.2 \mathrm{~km}$ west of the border of the map area, the most recent landslide began during the winter of 2000 and was still active during writing; the landslide has destroyed a house above the south bank of the Colorado River (Scott and others, 2001). Also, young landslides too small to map have damaged a sewage treatment plant and an irrigation pump station in the map area.

Many of the older landslide deposits (Olso) in the southwestern part of the map area formed on unstable slopes that are underlain by the Brushy Basin Member of the Morrison Formation ( $\mathrm{Jmb})$. The Brushy Basin Member of the Morrison Formation contains abundant expansive clays that have a high shrink-swell potential. These expansive clays reduce the shear strength of the Brushy Basin Member $(\mathrm{Jmb})$ so that landslides commonly displace the Brushy Basin Member and overlying Burro Canyon $(\mathrm{Kb})$ and Dakota Formations $(\mathrm{Kd})$. Some of these landslides lack distinctive landforms such as crescentic headwall scarps and lobate toes, but they do have hummocky surfaces. Rejuvenated parts of these landslides may have crescentic headwall scarps. Deposits derived from the Dakota Formation (Kd) and the Burro Canyon Formation $(\mathrm{Kb})$ contain blocks of rock as long as $6 \mathrm{~m}$. A particularly large landslide complex along the upper part of Little Park Road extends over an area of $2.5 \mathrm{~km}$ by $3.5 \mathrm{~km}$. This landslide was mapped as the Jacobs Ladder fault complex by Lohman (1963). An older landslide deposit between the Gunnison River and Horse Point has morphologies that suggest that the oldest parts of the deposits are closest to the river and the youngest are closest to Horse Point. The river appears to be eroding these deposits as they slide downhill in a conveyor-belt fashion. Landslide deposits may be prone to continued movement or reactivation due to natural as well as human-induced processes. Excavations and other disturbances on either preexisting landslides or gentle dipslopes underlain by the Mancos-Dakota-Burro Canyon-Morrison sequence of strata may cause sliding such as that in The Redlands area and the residential areas along Little Park Road. At the base of Little Park Road, a small incipient landslide deposit is characterized by southern and southwestern dips rather than northeastern dips parallel to the dipslope. 


\section{GULLYING}

Gullying is the process in which erosion of soil or easily eroded rock by running water forms distinct, narrow channels. Usually these channels carry water only during and immediately after heavy rains. In the Grand Junction quadrangle, units Qa, Qac, and $\mathrm{Km}$ are prone to gullying (table 4). Over time, the process of gullying can lead to the formation of deep channels that can disrupt roads and irrigation systems, clog downstream areas with excess sediment, and ruin the environmental quality and aesthetic attraction of areas.

\section{PIPING}

Piping is the process whereby erosion by percolating water results in the formation of tunnels (pipes) through which fine-grained material is removed. In the Grand Junction quadrangle, those areas underlain by units $\mathrm{Qa}$ and $\mathrm{Qac}$ are prone to piping in some areas (table 4). Piping can lead to the formation of large cavities that may be prone to collapse, thereby endangering roads, irrigation systems, power lines, and structures. In addition, eolian and sheetwash deposits ( $\mathrm{Qse}$ ) are probably susceptible to piping and possibly to hydrocompaction.

\section{EXPANSIVE SOILS AND BEDROCK}

Soils or bedrock that tend to shrink or swell due to changes in moisture content are commonly known as expansive soils or bedrock. Expansive soils are common in those areas underlain by sedimentary rock containing clay minerals or in surficial deposits derived from those bedrocks. The potential volume change of a given soil or bedrock depends on the type and amount of clay minerals it contains. Due to differential expansion, concrete foundations, floors, and walls may develop cracks, doors may not close, and buildings may tilt slightly. It has been estimated that as many as 60 percent of homes built on swelling clays will undergo minor damage whereas 10 percent may suffer significant damage (Jones and Holtz, 1973). In semiarid areas such as the Grand Junction quadrangle, soils containing swelling clays will commonly have a characteristic "popcorn" texture when dry.

The Mancos Shale $(\mathrm{Km})$ or alluvium and colluvium (Qac) derived from the Mancos Shale are known to contain varying amounts of swelling clays. These areas may have moderate to high swelling potential and, in addition, may contain sulfate minerals, such as thenardite, which are corrosive to conventional concrete and metal pipes. Because of its high clay content, the surface of the Mancos Shale becomes sticky and very slippery when wet making unimproved roads virtually impassable.

The Brushy Basin Member of the Morrison Formation (Jmb) contains abundant, expansive clays. Watering of lawns in The Redlands area has been sufficient to locally activate movement of expansive soils and clays on and in the Brushy Basin Member of the Morrison as well as in some of the overlying map units. Damage to homes and roads is evident in places. Smectitic clays are alteration products of volcanic ash; therefore, these clays retain the higher radioactivity of the volcanic ash. Cole and others (1999) used a portable gamma-ray spectrometer to detect higher concentrations of gamma-ray producing radioactive elements in those parts of the strata that have the highest concentrations of expansive clays and, therefore, are the most conducive to landsliding. Surficial deposits that contain debris from the Brushy Basin Member are particularly susceptible to shrinking, swelling, and hydrocompaction, which makes them an unstable base for roads or foundations of buildings.

\section{FLOODING}

Most of the town of Grand Junction is relatively safe from flood hazard from the Colorado River. However, several areas are within the boundaries of the 100-year flood (U.S. Corps of Engineers, 1973). An area along the northern side of the Colorado River north of Watson Island State Park lies within the boundaries of the 100-year flood. Riverside Park and adjoining areas are also within the limits of the 100-year flood, as is the community of Rosevale and much of the area in the vicinity of Connecticut Lake. As urbanization of the Grand Valley continues, care should be taken to avoid those areas south of town mapped as Qalc1 as these areas are prone to periodic flooding. Low-lying areas within map unit Qalc2 may also be subject to Colorado River floods of large magnitude.

In addition, low-lying areas within map unit $\mathrm{Qa}$ are prone to flash floods or debris flows caused by intense thunderstorms in their headward regions. The resulting flash floods present a serious geologic hazard to structures and roads that are close to the flood-prone intermittent streams where these streams exit through narrow canyons, such as onto The Redlands area where boulders more than $2 \mathrm{~m}$ in diameter have been moved during historic and prehistoric flash floods.

\section{GEOLOGIC RESOURCES}

The Grand Junction quadrangle contains abundant sand and gravel resources. Many of the gravel pits are indicated on the map and are mainly located in map unit Qalc1. These deposits consist chiefly of well-sorted, rounded and well-rounded pebble-cobble gravel. Along the Colorado River, upstream from the confluence with the Gunnison River, clasts consist largely of basaltic rocks, quartzite, micaceous red sandstone, gray fine- to medium-grained granitic rocks, and "oil shale" of the Green River Formation. Downstream from the confluence of the Colorado and Gunnison Rivers clasts consist of similar rock types with the addition of intermediate-composition volcanic rocks derived from the San Juan Mountains to the south. The gravel matrix generally consists of pale-brown (10YR 6/3) silty sand and sand. The gravels are commonly overlain by $1-2 \mathrm{~m}$ of overbank and possibly eolian materials consisting of 
massive, light-yellowish-brown (10YR 6/4) silty fine sand and fine sand. The gravels also contain about 5-10 percent "oil shale" clasts, derived from exposures of the Green River Formation along the flanks of Grand Mesa to the east, which have low bearing strength. Hence, these gravels are suitable for road base, but may be unsuitable as an aggregate for concrete and asphalt. A bentonite quarry has been excavated in the Brushy Basin Member of the Morrison Formation ( $\mathrm{Jmb}$ ) in the southwest part of the map area near Little Park Road. An important geologic resource of Grand Junction and Grand Valley is the intrinsic beauty of the rocks exposed in the margin of the Uncompahgre Plateau, which attracts many visitors to Colorado National Monument and surrounding Bureau of Land Management lands.

\section{ACKNOWLEDGMENTS}

Several land owners and corporations provided access to private land. In numerous ways U.S. Geological Survey colleagues and volunteers were helpful: Constructive reviews by Scott Lundstrom and Ric Page are gratefully acknowledged. Paco Van Sistine helped with GIS problems that made the preparation for publication much easier. The volunteer editorial assistance of Anne Harding is deeply appreciated. Randy Schumann has instigated several changes in GIS procedures that overcame bottlenecks in map preparation. Advice by Ralph Shroba in answer to many large and small questions about surficial deposits helped significantly.

\section{REFERENCES CITED}

Allen, J.R.L., 1970, Physical processes of sedimentation: London, George Allen and Unwin, $248 \mathrm{p}$.

American Geological Institute, 1982, Grain-size scales used by American geologists, modified Wentworth scale, in Data sheets (2nd ed.): Falls Church, Va., American Geological Institute, sheet 17.1.

Anderson, O.J., and Lucas, S.G., 1998, Redefinition of Morrison Formation (Upper Jurassic) and related San Rafael Group strata, southwestern U.S.: Modern Geology, v. 22, p. 39-69.

Aubrey, W.M., 1998, A newly discovered, widespread fluvial facies and unconformity marking the upper Jurassic/Lower Cretaceous boundary, Colorado Plateau: Modern Geology, v. 22, p. 209-233.

Boggs, S., Jr., 1995, Principles of sedimentology and stratigraphy: Englewood Cliffs, N.J., Prentice Hall, edition 2, 774 p.

Campbell, C.V., 1967, Lamina, laminaset, bed and bedset: Sedimentology, v. 8, p. 7-26.

Carrara, P.E., 2001, Geologic map of the Clifton quadrangle, Mesa County, Colorado: U.S Geological Survey Miscellaneous Field Studies Map MF-2359, scale 1:24,000.

Cole, R.D., 1987, Cretaceous rocks of the Dinosaur Triangle, in Averett, W.R., ed., Paleontology and geology of the Dinosaur Triangle: Grand Junction Geological Society 1987 Guidebook, p. 21-35

Cole, R.D., Hood, W.C., and Scott, R.B., 1999, Sedimentological reevaluation, high-resolution gamma-ray log, and landslide hazards of the stratigraphic section at Colorado National Monument, western Colorado: Geological Society of America Abstracts with Programs, v. 31, no. 7, p. A-283.

Cole, R.D., and Moore, G.E., 1994, Sequence stratigraphy of Cedar Mountain-Dakota interval, western and southern Piceance Creek basin, Colorado: American Association of Petroleum Geologists Annual Convention Program, v. 3, p. 124.

Craig, L.C., 1981, Lower Cretaceous rocks of southwestern Colorado and southeastern Utah, in Geology of the Paradox Basin: Rocky Mountain Association of Geologists, p. 195-200.

Davis, G.H., 1999, Structural geology of the Colorado Plateau region of southern Utah, with special emphasis on deformation bands: Geological Society of America Special Paper 342, $157 \mathrm{p}$.

Dunham, R.J., 1962, Classification of carbonate rocks according to depositional textures, in Ham, W.E., ed., Classification of carbonate rocks: American Association of Petroleum Geologists Memoir 1, p. 108-121.

Ekdale, A.A., Bromley, R.G., and Pemberton, S.G., eds., 1984, Ichnology - the use of trace fossils in sedimentology and stratigraphy: Society of Economic Paleontologists and Mineralogists, Short Course Notes 15, 317 p.

Folk, R.L., 1974, Petrology of sedimentary rocks: Austin, Texas, Hemphill Publishing Co., 182 p.

Fouch, T.D., Lawton, T.F., Nichols, D.J., Cashion, W.B., and Cobban, W.A., 1983, Patterns and timing of synorogenic sedimentation in Upper Cretaceous rocks of central and northeast Utah, in Reynolds, M.W., and Dolly, E.D., eds., Mesozoic paleogeography of the westcentral United States: Denver, Colo., Rocky Mountain Section of the Society of Economic Paleontologists and Mineralogists Rocky Mountain Paleogeography Symposium 2, p. 305-336.

Geological Society of America, 1999, Geological time scale: Boulder, Colo., Geological Society of America.

Gile, L.H., Peterson, F.F., and Grossman, R.B., 1966, Morphological and genetic sequences of carbonate accumulation in desert soils: Soil Science, v. 101, p. 347-360.

Hansen, W.R., ed., 1991, Suggestions to authors of the reports of the United States Geological Survey, seventh edition: Washington, D.C., U.S. Government Printing Office, 289 p.

Hunt, C.B., 1956, Cenozoic geology of the Colorado Plateau: U.S. Geological Survey Professional Paper 279, 99 p. 
Ingram, R.L., 1954, Terminology for the thickness of stratification and parting units in sedimentary rocks: Geological Society of America Bulletin, v. 65, p. 937-938.

Izett, G.A., and Wilcox, R.E., 1982, Map showing localities and inferred distributions of the Huckleberry Ridge, Mesa Falls, and Lava Creek ash beds (Pearlette family ash beds) of Pliocene and Pleistocene age in the Western United States and Southern Canada: U.S. Geological Survey Miscellaneous Investigations Series Map I-1325, scale 1:4,000,000.

Jochim, C.L., Rogers, W.P., Truby, J.O., Wold, R.L., Jr., Weber, G., and Brown, S.P., 1988, Colorado landslide hazard mitigation plan: Colorado Geological Survey Bulletin 48, 149 $p$

Jones, D.E., and Holtz, W.G., 1973, Expansive soils- the hidden disaster: Civil Engineering, American Society of Civil Engineers, v. 43, p. 49-51.

Kowallis, B.J., Christiansen, E.H., and Deino, A.L., 1991, Age of the Brushy Basin Member of the Morrison Formation, Colorado Plateau, western USA: Cretaceous Research, v. 12, p. 483-493.

Kowallis, B.J., Christiansen, E.H., Deino, A.L., Peterson, Fred, Turner, C.E., Kunk, M.J., and Obradovich, J.D., 1998, The age of the Morrison Formation: Modern Geology, v. 22, p. 235-260.

Lohman, S.W., 1963, Geologic map of the Grand Junction area, Colorado: U.S. Geological Survey Miscellaneous Investigations Map I404, scale 1:31,680.

-1965, Geology and artesian water supply, Grand Junction area, Colorado: U.S. Geological Survey Professional Paper 451, 149 p. 1981, The geologic story of Colorado $\mathrm{Na}$ tional Monument: U.S. Geological Survey Bulletin 1508, 142 p.

Marvin, R.F., Mehnert, H.H., and Montjoy, W.M., 1966, Age of the basalt cap on Grand Mesa, in Geological Survey Research 1966: U.S. Geological Survey Professional Paper 550-A, p. A81.

McKee, E.D., and Weir, G.W., 1953, Terminology for stratification and cross-stratification in sedimentary rocks: Geological Society of America Bulletin, v. 64, p. 381-390.

Miller, D.M., Nilsen, T.H., and Bilodeau, W.L., 1992, Late Cretaceous to early Eocene geologic evolution of the U.S. Cordillera, in Burchfiel, B.C., Lipman, P.W., and Zoback, M.L., eds., The Cordilleran Orogen-Coterminous U.S.: Boulder, Colo., Geological Society of America, The Geology of North America, v. G-3, p 205-260.

Munsell Color, 1973, Munsell soil color charts: Baltimore, Md,. Kollmorgen Corp., Macbeth Division.

North American Commission on Stratigraphic Nomenclature, 1983, North American strati graphic code: American Association of Petroleum Geologists Bulletin, v. 67, p. 841875.

O'Sullivan, R.B., 1980, Stratigraphic sections of Middle Jurassic San Rafael Group and related rocks from the Green River to the Moab area in east-central Utah: U.S. Geological Survey Miscellaneous Field Studies Map MF-1247, 1 sheet.

1991, Correlation of Middle Jurassic San

Rafael Group and related rocks from Kane Springs, Utah, to Uravan, Colorado: U.S. Geological Survey Oil and Gas Investigations Chart OC-134, 1 sheet.

1992, The Jurassic Wanakah and Morrison Formations in the Telluride-Ouray-Western Black Canyon area of southern Colorado: U.S. Geological Survey Bulletin 1927, 24 p.

O'Sullivan, R.B., and Pipiringos, G.N., 1983, Stratigraphic sections of Middle Triassic Entrada Sandstone and related rocks from Dewey Bridge, Utah, to Bridgeport, Colorado: U.S Geological Survey Oil and Gas Investigations Chart OC-122, 1 sheet.

Padian, K., 1989, Presence of dinosaur Scelidosaurus indicates Jurassic age for the Kayenta Formation (Glen Canyon Group, northern Arizona): Geology, v. 17, p. 438441

Pemberton, S.G., MacEachern, J.A., and Frey, R.W., 1992, Trace fossil facies models-environmental and allostratigraphic significance, in Walker, R.G., and James, N.P., eds., Facies models, response to sea level change: Geological Association of Canada, p. 47-72.

Peterson, Fred, 1988a, Stratigraphy and nomenclature of Middle and Upper Jurassic rocks, western Colorado Plateau, Utah and Arizona, in Revisions to stratigraphic nomenclature of Jurassic and Cretaceous rocks of the Colorado Plateau: U.S. Geological Survey Bulletin 1633-B, p. 17-56.

1988b, Pennsylvanian to Jurassic eolian transport systems in the Western United States: Sedimentary Geology, v. 56, p. 207-260. 1994, Sand dunes, sabkhas, streams, and shallow seas-Jurassic paleogeography in the southern part of the Western Interior basin, in Caputo, M.V., Peterson, J.A., and Franczyk, K.J., eds., Mesozoic systems of the Rocky Mountain region, USA: Rocky Mountain Section of SEPM (Society for Sedimentary Geology), p. 233-272.

Peterson, Fred, and Pipiringos, G.N., 1979, Stratigraphic relationships of the Navajo Sandstone to Middle Jurassic formations in parts of southern Utah and northern Arizona: U.S. Geological Survey Professional Paper 1035-B, p. B1-B43.

Peterson, Fred, and Turner, C.E., 1998, Stratigraphy of the Ralston Creek and Morrison Formations (Upper Jurassic) near Denver, Colorado: Modern Geology, v. 22, p. 3-38. 
Pettijohn, F.J., Potter, P.E., and Siever, R., 1973, Sand and sandstone: New York, SpringerVerlag, 553 p.

Phillips, W.A., 1986, Cobble aquifer investigation: Colorado River Basin Salinity Control Project, Grand Junction Office, U.S. Bureau of Reclamation, $20 \mathrm{p}$.

Picard, M.D., 1971, Classification of fine-grained sedimentary rocks: Journal of Sedimentary Petrology, v. 41, p. 179-195.

Pierce, K.L., Obradovich, J.D., and Friedman, I., 1976, Obsidian hydration dating and correlation of Bull Lake and Pinedale glaciations near West Yellowstone, Montana: Geological Society of America Bulletin, v. 87, p. 703-710.

Piety, L.A., 1981, Relative dating of terrace deposits and tills in the Roaring Fork Valley, Colorado: Boulder, Colo., University of Colorado M.S. thesis, $209 \mathrm{p}$.

Pipiringos, G.N., and O'Sullivan, R.B., 1978, Principal unconformities in Triassic and Jurassic rocks, Western Interior United States-A preliminary survey: U.S. Geological Survey Professional Paper 1035-A, 29 p.

Potter, P.E., Maynard, J.B., and Pryor, W.A., 1980, Sedimentology of shale: New York, SpringerVerlag, $306 \mathrm{p}$.

Powers, M.C., 1953, A new roundness scale for sedimentary particles: Journal of Sedimentary Petrology, v. 23, p. 117-119.

Richmond, G.M., and Fullerton, D.S., 1986, Introduction to Quaternary glaciations in the United States of America, in Richmond, G.M., and Fullerton, D.S., eds., Quaternary glaciations in the United States of America: Quaternary Science Reviews, v. 5, p. 3-10.

Rock-Color Chart Committee, 1951, Rock-Color Chart: Boulder, Colo., Geological Society of America.

Schneider, E.J., 1975, Surficial geology of the Grand Junction-Fruita area, Mesa County, Colorado: Fort Collins, Colo., Colorado State University M.S. Thesis, 132 p.

Schwochow, S.D., 1978, Mineral resources survey of Mesa County - a model study: Colorado Geological Survey Resource Series 2, 110 p.

Scott, R.B., Harding, A.E., Hood, W.C., Cole, R.D., Livaccari, R.F., Johnson, J.B., Shroba, R.R., and Dickerson, R.P., 2001, Geologic map of Colorado National Monument and adjacent areas, Mesa County, Colorado: U.S. Geological
Survey Geologic Investigations Series I-2740, scale 1:24,000.

Scott, R.B., Hood, W.C., Johnson, James, Tausch, Robin, Sexton, T.O., and Perrotti, Patrick, 1999, Charcoal record in sediments and fire ecology history of piñon-juniper uplands of the Uncompahgre uplift, western Colorado: Geological Society of America Abstracts with Programs, v. 31 , no. 7, p. A-482-483.

Stone, D.S., 1977, Tectonic history of the Uncompahgre uplift, in Exploration Frontiers of the Central and Southern Rockies-1977 Symposium: Rocky Mountain Association of Geologists, p. 23-30.

Stuiver, Minze, Reimer, P.J., Bard, Edouard, Beck, J.W., Burr, G.S., Hughen, K.A., Kromer, Bernd, McCormac, Gerry, van der Plicht, Johannes, and Spurk, Marco, 1998, Intcal98 radiocarbon age calibration, 24,000-0 cal BP: Radiocarbon, v. 40, no. 3, p 1041-1083.

U.S. Corps of Engineers, 1973, Flood plain information Colorado and Gunnison Rivers, Grand Junction, Colorado: Prepared for the Western Colorado Regional Planning Commission March 1973; Sacramento, Calif., Department of the Army, Corps of Engineers, 24 p.

Varnes, D.J., 1978, Slope movement types and process, in Schuster, R.L., and Krizek, R.J., eds., Landslides, analysis, and control: $\mathrm{Na}$ tional Academy of Sciences, Transportation Research Board Special Report 176, p. 1133.

Whitney, J.W., 1981, Surficial geologic map of the Grand Junction $1^{\circ} \times 2^{\circ}$ quadrangle, Colorado and Utah: U.S. Geological Survey Miscellaneous Investigations Series Map I-1289, scale 1:100,000.

Whitney, J.W., Piety, L.A., and Cressman, S.L., 1983, Alluvial history in the White River basin, northwest Colorado: Geological Society of America Abstracts with Programs, v. 15, p. 328.

Willis, G.C., 1994, Geologic map of the Harley dome quadrangle, Grand County, Utah: Utah Geological Survey Map M-157, scale $1: 24,000$.

Young, R.G., 1959, Cretaceous deposits of the Grand Junction area, Garfield, Mesa, and Delta Counties, Colorado: Rocky Mountain Association of Geologists, 11th field conference, p. 17-25. 